\title{
A Review on Curability of Cancers: More Efforts for Novel Therapeutic Options Are Needed
}

\author{
Shuncong Wang ${ }^{1}{ }^{\oplus}$, Yewei Liu ${ }^{1} \oplus$, Yuanbo Feng ${ }^{1}$, Jian Zhang ${ }^{2}$, Johan Swinnen ${ }^{1}$, Yue $\mathrm{Li}^{3, *}$ and \\ Yicheng $\mathrm{Ni}^{1, * \mathbb{C}}$ \\ 1 KU Leuven, Campus Gasthuisberg, Faculty of Medicine, 3000 Leuven, Belgium; \\ shuncong.wang@kuleuven.be (S.W.); yyewei.liu@outlook.com (Y.L.); yuanbo.feng@kuleuven.be (Y.F.); \\ j.swinnen@kuleuven.be (J.S.) \\ 2 Laboratories of Translational Medicine, Jiangsu Province Academy of Traditional Chinese Medicine, \\ Nanjing 210028, China; zjwonderful@hotmail.com \\ 3 Shanghai Key Laboratory of Molecular Imaging, Shanghai University of Medicine and Health Sciences, \\ Shanghai 201318, China \\ * Correspondence: liy_16@sumhs.edu.cn (Y.L.); yicheng.ni@med.kuleuven.be (Y.N.); \\ Tel.: +862133759000 (Y.L.); +3216330165 (Y.N.); Fax: +3216343765 (Y.N.)
}

Received: 14 October 2019; Accepted: 4 November 2019; Published: 13 November 2019

\begin{abstract}
Cancer remains a major cause of death globally. Given its relapsing and fatal features, curing cancer seems to be something hardly possible for the majority of patients. In view of the development in cancer therapies, this article summarizes currently available cancer therapeutics and cure potential by cancer type and stage at diagnosis, based on literature and database reviews. Currently common cancer therapeutics include surgery, chemotherapy, radiotherapy, targeted therapy, and immunotherapy. However, treatment with curative intent by these methods are mainly eligible for patients with localized disease or treatment-sensitive cancers and therefore their contributions to cancer curability are relatively limited. The prognosis for cancer patients varies among different cancer types with a five-year relative survival rate (RSR) of more than $80 \%$ in thyroid cancer, melanoma, breast cancer, and Hodgkin's lymphoma. The most dismal prognosis is observed in patients with small-cell lung cancer, pancreatic cancer, hepatocellular carcinoma, oesophagal cancer, acute myeloid leukemia, non-small cell lung cancer, and gastric cancer with a five-year RSR ranging between $7 \%$ and $28 \%$. The current review is intended to provide a general view about how much we have achieved in curing cancer as regards to different therapies and cancer types. Finally, we propose a small molecule dual-targeting broad-spectrum anticancer strategy called OncoCiDia, in combination with emerging highly sensitive liquid biopsy, with theoretical curative potential for the management of solid malignancies, especially at the micro-cancer stage.
\end{abstract}

Keywords: cancer treatment; survival; theragnostics; curability and cancer epidemiology

\section{Introduction}

Cancer covers a wide spectrum of diseases characterized by uncontrolled and mostly aggressive cell growth, which is driven by down-regulation of tumour-suppressing genes and/or up-regulation of tumour-promoting genes [1]. Although the first cancer case was systematically reported in 1845, it is only in recent decades that in-depth understanding of its biology and pathology has gradually been achieved and tremendous efforts to eliminate cancer have been made [2]. Data from population-based cancer registries estimate a total of 1,762,450 new cases and 606,880 cancer-related deaths in the US in 2019, making it the second leading cause of death [3]. In China, a country with the world's largest population of over 1.4 billion, 4,292,000 new cancer diagnoses and 2,814,000 cancer-related deaths 
were reported in 2015, posing a huge burden on both finance and healthcare systems [4]. To counteract the alarming mortality rates, the National Cancer Act of 1971 was launched in the US with the aim to deepen understanding of cancer biology and ultimately prompt the development of more effective cancer therapeutics, which has been, nearly half a century later, upgraded to a newer cancer moonshot funding $[5,6]$. Benefiting from the advances in clinical therapeutics and management, prolongation in survival for many cancer types has been realized, such as non-small cell lung cancer (NSCLC), hepatocellular carcinoma (HCC), breast cancer, and multiple myeloma, among others [6-9]. However, it is still premature for us to celebrate the success of curing cancer, as some flaws do exist, e.g., no survival improvement was observed over the past four decades in solid malignancies such as sarcoma and small cell lung cancer (SCLC) $[9,10]$.

The present review, by studying the literature and database, aims to (1) deliver a general landscape of currently available cancer treatments, along with their advantages and disadvantages and future perspective; (2) demonstrate the contribution of these methods to the curability of cancer; (3) quantitatively show the current landscape of cancer diagnosis and prognosis by cancer type, based on data from a population-based database; and (4) put forward a potential liquid biopsy-OncoCiDia strategy, which may revolutionize the future of cancer treatment.

\subsection{Mortality of Cancer Cells Caused by Therapies}

The elimination of cancer cells can be achieved either by complete removal or by induction of cell death. In terms of cell death, which can be either active or passive, active cell death includes apoptosis, autophagy, ferroptosis, activation-induced cell death, mitotic catastrophe, and pyroptosis [11]. The disruption of deoxyribonucleic acid (DNA) structure in the nuclei of cancer cells is a major mechanism for chemotherapy- and radiotherapy-induced apoptosis, and mitotic catastrophe is a molecular event prior to apoptosis [12-14]. Additionally, necrosis, as a passive form of cell death following injury and ischemia, can also be induced by chemotherapy, radiotherapy, ablation, and transcatheter arterial chemoembolization (TACE) [15-18].

\subsection{Cancer Staging}

Heterogeneous progressiveness at diagnosis necessitates a proper classification of cancer stage, which is essential for clinical decision-making and treatment planning. The tumour-node-metastasis (TNM) staging system is the most widely adopted staging system for most cancer types (except for haematological malignancies and brain tumours), and it categorizes patients into four major categories: I, II, III and IV [19]. Stage I patients refer to cases harbouring cancers that are confined within the original organ and are highly curable, whereas stage IV patients are metastatic cases and barely curable. Stage II and stage III patients are with intermediate potentials to be cured, to whom multidisciplinary modalities are applied to maximally prolong their survival [20-22]. Due to the futility of single therapeutics in the most advanced cases, cancer cure in these cases could be realized with the "log-kill" model, i.e., surgery or the alike removes a great majority of cancer cells, followed by further chemoand radiotherapy cleansing; finally, anti-cancer immunity of the patient could be just strong enough to kill the remaining cancer cells [23].

\subsection{Concepts of Cancer Cure}

Literally, to cure refers to eliminate a disease or condition without any relapse. However, the relapsing nature (within months or years) after remission makes the traditional definition of "cure" impractical and rarely mentioned in oncology. The cure of cancer implies not only numerically long survival time, but also equal life expectation between properly treated patients and corresponding cancer-free population. A plausible and empirical criterion for curability is the maintenance of recurrence-free survival for more than 10 years after effective treatments [24]. However, a widely accepted notion for cancer cure in clinic refers to the maintenance of complete remission for five years [25]. Based on this notion, the overall five-year relative survival rate (RSR) for cancer patients 
was $48.9 \%$ in the 1970 s and this figure climbed to $69.3 \%$ in the 2010 s, implying that approximately $30 \%$ of cancer patients still fail to be cured [26].

\subsection{Measurable for Outcomes of Cancer Patients}

Assessment of treatment response is pivotal for evaluation of anti-cancer therapies, subsequent treatment planning, and prognosis prediction. Currently available measurable includes survival time/rate and tumour size changes evaluated by imaging. Overall survival (OS), defined as the period from randomization to death, is the gold standard for evaluation of treatment outcome. However, it requires a large sample size as well as long-term follow-up, which is labour intensive and costly. To tackle this and accelerate drug approval, progression-free survival (PFS) or disease-free survival (DFS) were proposed as surrogates and defined as the interval between randomization and objective tumour progression $[27,28]$. In addition, objective response rate, the proportion of patients with tumour burden reduction classified as either complete remission or partial remission based on response evaluation criteria in solid tumour (RECIST) criteria, correlates well with PFS and serves as an early predictive marker for PFS [29]. The RECIST criteria evaluates therapeutic response by assessment of cancer diameter changes before and after treatment, firstly issued in 2000 [30]. Afterwards, to counteract with the "pseudoprogression" phenomenon during immune checkpoint inhibitors (ICIs) treatment, a modified "iRESCIST" was proposed in 2009 [31].

Besides the above-mentioned measurables at an individual level, epidemiologists and healthcare providers are more concerned about the prevalence of cancer deaths at a population level and thus, cancer-specific survival and RSR are proposed [32]. Cancer-specific survival is the percentage of patients who did not die from the index cancer at a specific time point. Alternatively, the RSR is defined as the ratio between the percentage of cancer patients who survive for a specific period and the percentage of comparable people (usually with the same sex and age) who survive the same period of time $[32,33]$. Of note, both methodologies have their own limitations, including dependence of accurate classification about cause of death, which is not always possible solely on a basis of clinical evaluation without autopsy, and dependence of comparable referential life table, respectively. And the extent of their difference varies by cancer types and age of diagnosis, with a greater deviation in lung cancer, brain tumour, and the elderly population [34].

\section{Current Cancer Therapies and Their Performances}

Current common cancer treatments include surgery (and its analogous ablation therapies), chemotherapy, radiotherapy, targeted therapy, and immunotherapy (Figure 1). The curative potential for each of these treatments varies and is largely dependent on cancer type, stage, patients' performance status, and so forth. Surgery alone can be curative in early-stage solid cancers. For instance, the current national comprehensive cancer network (NCCN) guideline recommends radical resection with curative intent and active postoperative surveillance for T1a stage NSCLC [35]. In the hyper-early stage of solid cancers that are sensitive to chemotherapy or radiotherapy, a monotherapy could also be sufficient for cancer cure [36-38]. However, a majority of cancer cases are diagnosed at advanced stages in which multimodality strategies are applied, aiming to maximally eliminate cancer cells and prolong patients' survival. Sadly, long-term survival by these methods are dissatisfactory in practice, and, therefore, the cornerstones of curing cancer still lie in early detection, followed by timely and sufficient treatment. The animal experiments covered by the current review have been approved by the KU Leuven University Ethics Committee (P147/2013). 


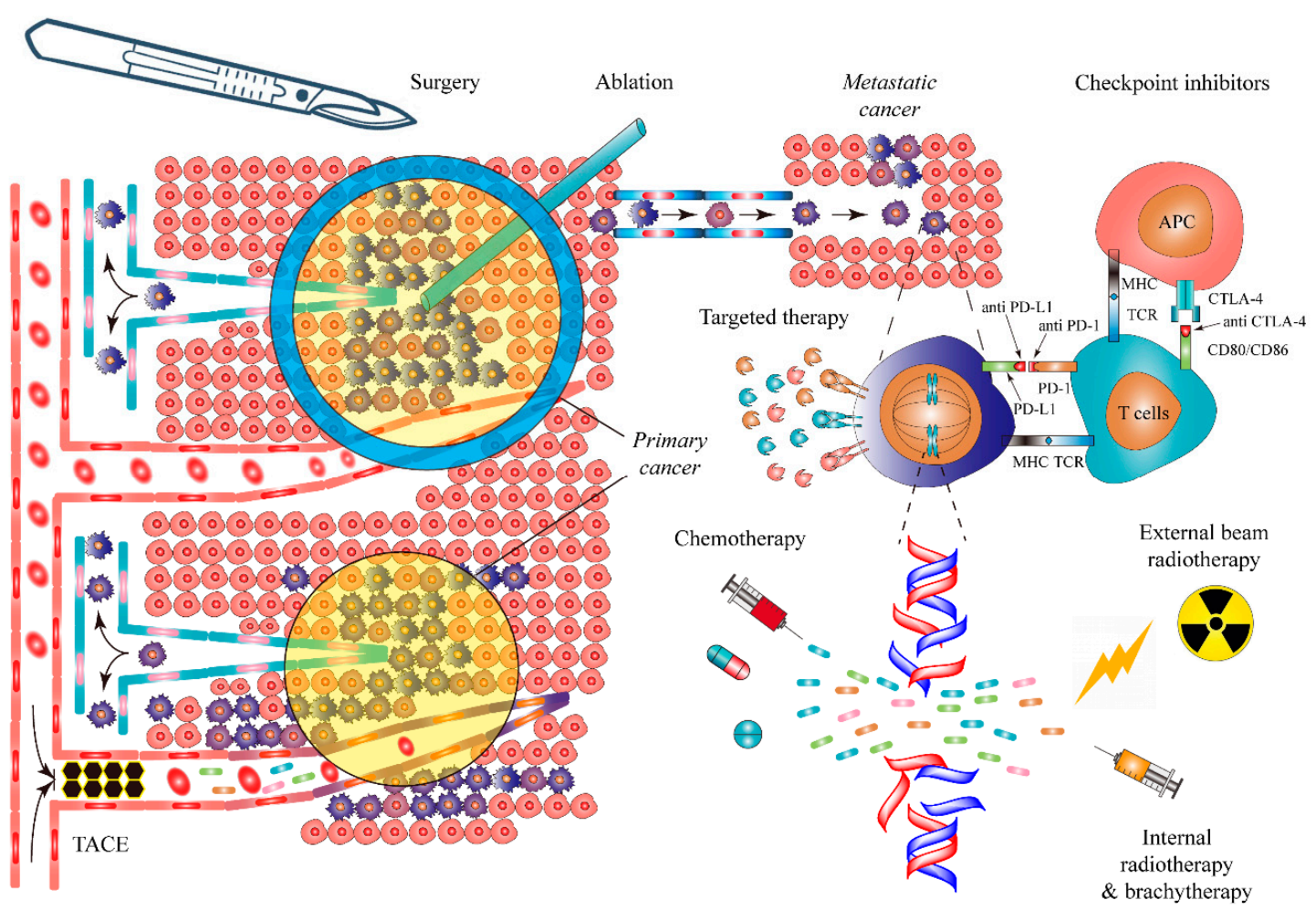

Figure 1. Current major therapeutics for cancer. In the primary site, local treatments, including surgery, imaging-guided interventional procedure, and radiotherapy, can be applied with curative intent. In metastatic disease, surgery, radiotherapy, immunotherapy, targeted therapy, and chemotherapy can be delivered, with palliative or even curative intent. Abbreviations: TACE: transcatheter arterial chemoembolization; APC: antigen-presenting cell; PD-1: programmed death-1; PD-L1: programmed death ligand-1; MHC: major histocompatibility complex; TCR: T cell receptor; CTLA-4: cytotoxic T-lymphocyte-associated protein 4; CD: cluster of differentiation.

\subsection{The Evolving Role of Surgery}

Surgery is a major pillar for clinical management of cancer. About $80 \%$ of 15.2 million newlydiagnosed cancer patients in 2015 require surgery across the globe and by 2030 this figure will increase to 45 million [39]. Besides preventive, diagnostic, and cosmetic purposes, surgery contributes substantially to the cure of solid cancer at their infancy by removal of cancer tissue and lymph node. It has served as the only curative therapy for most solid tumours at an early stage, such as oesophagal cancer, gastric cancer, and colorectal cancer (CRC), to mention only a few (Table 1). However, a majority of cancer cases were diagnosed at locally advanced or even metastatic stages, limiting the applicability of curative surgery. The development of oncological surgery mainly focuses on decreasing its invasiveness that, on a basis of equivalent anticancer efficacy, may help minimize perioperative complications and postoperative side-effects, and ultimately improve patients' quality of life. Laparoscopic surgery has shown equivalent anticancer efficacy and lower incidence or intensity of complications, compared with open surgery in gastric cancer and colorectal cancer [40,41]. However, critics indicate that high-quality evidence from well-designed randomized clinical trials with sound methods is needed to justify the routine implementation of laparoscopic gastrectomy [42]. Furthermore, laparoscopic surgery in pancreatic or periampullary cancer and cervical cancer was associated with an inferior oncologic outcome compared with open surgery [43-46]. Endoscopic surgery has been applied in early oesophageal cancer, gastric cancer, and colorectal cancer in carefully selected patients in expert centres, such as T1a gastric cancer without lymph node metastasis [47-50]. Despite versatile flexibility of robotic surgery, its associated survival benefit and cost-effectiveness have been disputed, especially in mastectomy and other cancer-related surgeries [51,52]. Concerns about minimally invasive surgery 
include long learning curve, dependence of centralization of cases in hospital with high volume of surgeons, limited eligibility (only for highly-selected patients), and higher cost [53-56]. As the alternatives to the above-mentioned open and minimally invasive surgeries, which make the entire tumour (and a layer of surrounding tissue as a safety margin) physically excised from the patient, a series of minimally invasive tumour ablation techniques have been developed. These virtual surgical techniques (Table 1) instantly kill the tumour (also with an intended 5-10 mm peritumoural safety margin) in situ without actual tumour removal by local delivery of either lethal temperatures such as hyperthermal radiofrequency ablation and hypothermal cryotherapy, or caustic chemicals such as absolute ethanol and acetic acid with resulted tissue necrosis [57-59]. Likewise, imaging-guided interventions such as TACE have been often applied for the treatment of mainly hepatic malignancies with palliative expectation $[60,61]$.

\subsection{The Pros and Cons of Radiotherapy}

Radiotherapy, including external beam radiotherapy (EBRT), internal radiotherapy, and brachytherapy, has been used in about $50 \%$ of cancer patients and exerts its anticancer activities by ionizing radiation, which structurally damage DNA or other macromolecules, resulting in mainly apoptosis in all exposed cells (Table 1) [62]. Radiotherapy is limited by complexity of radiobiology, difficult achievement of perfectly conformal dose distribution, and risk of secondary malignancy [63]. EBRT can be classified as different subtypes, based on the emitted particles: photons, electrons, and particles (proton, neutron, and heavy ion) [64]. Heavy ion refers to particles having one or more units of electric charge and a mass exceeding that of the Helium-4 nucleus (alpha particle) [65]. Photon radiotherapy, currently the most frequently used subtype, can generate free radicals and cause single strand DNA damage [66]. Electron radiotherapy has a short penetration, after which the energy drops sharply and therefore it is mostly used in superficial cancer [67]. Particle radiotherapy, delivering high-energy radiation, may form a dose peak near the end of penetration, namely Bragg peak, which enables higher dose in cancer tissue, induction of double strand DNA damage in a less oxygen-dependent manner, and better sparing of surrounding normal tissue [68]. Particle radiotherapy has become increasingly popular, especially over the past two decades [69]. Until the end of 2016, 174,512 patients received particle therapy globally, with 149,345 receiving proton therapy and 21,580 receiving carbon ion therapy [70]. However, widespread use of particle radiotherapy was halted by its tremendous cost and a paucity of solid clinical evidence [71]. EBRT is usually administrated in combinatory settings in most cancer cases, except for localized cancer cases with high sensitivity like lymphoma and seminoma. To achieve a possible curative effect with radiotherapy, a typical requirement is to reach a cumulative radiation dose ranging from 50-80 Gy for most cancer types, with 30 Gy in lymphoma [72,73]. The development of EBRT mainly focuses on two directions: better sparing of normal tissue by precise delivery and enhanced cancer control. The preciseness of delivery depends on the accurate delineation of the extent of tumour, developing from computed tomography (CT) to positron emission tomography (PET)/CT, a method incorporating metabolic information [74]. Currently, many linear accelerators are equipped with CT imaging, which can confirm the tumour location before delivery, namely image-guided radiation therapy [75]. Intensity-modulated radiation therapy (IMRT), a form of precision radiotherapy, was developed to enable the formation of a high-dose region with conformal complexity and proximity to vital tissue; an analog to IMRT is volumetric-modulated arc therapy, which requires short delivery time. Additional technical developments to achieve both higher conformity and possibly greater anti-cancer efficacy include protons and heavy ions therapy [76,77]. Enhanced cancer control can be achieved using various methods. Hypofractionation, namely stereotactic body radiation therapy, was proposed for its additional indirect effects like vascular collapse and immune effects in intracranial tumours; its application in extracranial tumours, namely stereotactic ablative radiotherapy, is currently being explored [78-82]. Additionally, combination therapies have strived to improve efficacy-the concurrent chemoradiotherapy, which is the cornerstone for a wide spectrum of cancers, is the most successful one. Radiotherapy may synergistically act with 
immunotherapy by releasing tumour antigens and a modulating microenvironment that facilitate recruitment of immune cells [83]. Another potential combination is with nanoparticles (NP). Gold $\mathrm{NP}$ can enhance radiosensitivity physically (producing photoelectron, Auger electron and low energy secondary electron), chemically (radical formation and chemical sensitization), and biologically (cell cycle disruption, oxidative stress, and DNA repair inhibition) [84-86]. For the DNA repair inhibition effect, nanoparticles exert an inhibitory effect by electric field generated from ionization of nanoparticles in the irradiated tissue [87]. NP, which can decompose $\mathrm{H}_{2} \mathrm{O}_{2}$ to generate $\mathrm{O}_{2}$, may help relieve the hypoxia, and enhance the immunogenicity of radiotherapy $[88,89]$. Currently, two NPs are under clinical trials: NBTXR3, a hafnium-based intratumourally administered NP and AGuIX, a gadolinium-based intravenously administered NP [90-92]. The addition of NBTXR3 to radiotherapy may help improve the pathological complete response rate of locally advanced soft-tissue sarcoma (16\% vs. $8 \%)$; the first clinical trial of AGuIX (NCT02820454) is finished, awaiting results [93,94]. Internal radiotherapy, which consists of radioactive isotope and radiopharmacy, was delivered based on intrinsic enrichment, intake of ${ }^{131} \mathrm{I}$ by thyroid cancer, and ${ }^{223} \mathrm{Ra}$ by bone cancer lesion; or artificial enrichment by intercalating radioactive isotopes with a receptor for tumour biomarker like CD20 antibody in Zevalin [95-97]. Brachytherapy was given directly or via a catheter implanting radioactive isotopes in or next to the cancer site, which produces high-energy radiation directly to the tumour [98]. Moreover, it shows better sparing of surrounding tissue for a sharp dose fall-off outside its limited penetration zone and a higher radiation dose in the cancer site, compared with EBRT [98]. Brachytherapy for breast cancer, prostate cancer, and cervical cancer is mainly preformed with ${ }^{125} \mathrm{I}$, a low dose rate isotope, which emits photons with energy up to $35.5 \mathrm{keV}$ by gamma decay and X-rays of energy between 27.2-31.7 keV by transition [99]. However, radiotherapy may also affect normal cells and induce side-effects due to imperfect conformal delivery, especially for fast-proliferative cells, like intestinal epithelia, bone marrow blood stem cells, etc. [100-102]. Additionally, patients are associated with a slightly higher incidence of secondary malignancy five years after receiving radiotherapy, especially those treated for breast cancer, mediastinal B-cell lymphoma, seminoma, prostate cancer, cervical cancer, and endometrium cancer [103-107]. Similarly, radiotherapy by radioactive iodine (RAI) for thyroid cancer could be associated with a higher incidence of secondary malignancies, especially in cases with a cumulative RAI dose over $150 \mathrm{mCi}$ [108]. RAI treatment of well-differentiated thyroid cancer showed $0.5 \%$ risk of developing acute and chronic myeloid leukemia [109].

\subsection{The Contribution of and Concerns about Chemotherapy}

Chemotherapy aims to eliminate cancer cells or inhibit their growth by altering abnormal cellular proliferation and metabolism, which are spectacular hallmarks of malignancies (Table 1). Chemotherapy is limited by a low response rate (except for a few sensitive cancer types), systematic side-effects, and risk of a secondary malignancy. The therapeutic efficacy of chemotherapy varies among different cancer types and satisfactory therapeutic effect is only shown for a limited spectrum of malignancies, including acute leukemia, Wilm's tumour and Ewing's sarcoma in children, and choriocarcinoma, lymphoma, endometrial cancer, and seminoma in adults. The general contribution of curative and adjuvant chemotherapy to five-year survival in adults is less than $2.5 \%$, providing an extra survival benefit of merely three months [110]. The addition of adjuvant chemotherapy was proposed to eliminate the remaining cancer cells after radical surgery and reduce the risk of postsurgical relapse; its associated survival improvement was practically observed in early stage epithelial ovarian cancer, esophagus cancer, etc. [111,112]. However, the survival benefit is absent in ypTis-2N0 rectal cancer and stage II colon cancer [113]. For advanced stage cancer, the complete remission rate for chemotherapy is generally low (7.4\%), regardless of cancer type and drug regimen [114]. Moreover, most of these cases relapse shortly after treatment. For instance, approximately $90 \%$ of metastatic NSCLC and pancreatic cancer patients progressed within 15 months after chemotherapy, with $90 \%$ of metastatic gastric and advanced esophagogastric cancer progressing within 24 months [115-118]. The contribution of chemotherapy to the survival of advanced hepatocellular carcinoma and pancreatic 
cancer is marginal $[115,119]$. Escalated chemotherapy is not necessarily associated with improved survival. The addition of cetuximab to postoperative chemotherapy for Ki-ras2 Kirsten rat sarcoma viral oncogene homolog (KRAS) exon 2 wild-type colorectal cancer was associated with a shorter PFS [120]. In contrast, the de-intensified regimen can help achieve equivalent anti-cancer efficacy in selected low-risk patients with breast cancer, colon cancer, or human papillomavirus-associated oropharyngeal squamous cell carcinoma [121-124]. The main hindrance to limited anti-cancer activity in chemotherapy is heterogeneous sensitivity in the diverse cancer cell population: indolent or insensitive cancer cells is the major resource of relapse [125]. Heterogeneous sensitivity can also be observed on an individual level: (1) response rate for solid tumours is generally lower than $50 \%$, with 20-30\% in NSCLC [126]; (2) highly responsive patients can be identified by biomarkers, including DNA damage immune response assay, promoter methylation for oesophageal adenocarcinoma patients, and 21-Gene Recurrence Score Prognostic Assay in early breast cancer patients [38,127-129]; and (3) higher response rate of pemetrexed in lung adenocarcinoma [130]. Accordingly, the role of chemotherapy in less-responsive cancer types has been challenged by targeted therapy or immunotherapy. In completely resected stage II-IIIA epidermal growth factor receptor (EGFR)-mutant NSCLC, adjuvant gefitinib is associated with better DFS than platinum-based chemotherapy [131]. In metastatic NSCLC, the first-line chemotherapy regimen remained a platinum-based regimen for decades, with a plateau response rate between 20\% and 30\% [126]. Currently, in patients with druggable targets (EGFR, anaplastic lymphoma kinase (ALK), and so on), targeted therapy has been recommended as the first line therapy [132,133]. More recently, the role of chemotherapy as first line treatment in mutation-negative advanced NSCLC was challenged by dual blockade of cytotoxic T-lymphocyte-associated protein 4 (CTLA-4) and programmed death 1 (PD1) (median OS: 14.9 vs. 17.1 months) [134].

In addition, chemotherapy is associated with a higher risk of a secondary malignancy, with increased risk of bone tumours and leiomyosarcoma after addition of an alkylating agent to radiotherapy for treatment of hereditary retinoblastoma [135]. The side-effects of chemotherapy are often systemic, especially on organs with rapidly growing cells, such as intestinal epithelia, bone marrow blood stem cells, and hair follicle cells [136].

\subsection{The Contribution of and Concerns about Targeted Therapy}

Targeted therapy was developed on the basis of in-depth understanding of cancer biology, and is frequently used in NSCLC, lymphoma, breast cancer, gastric cancer, and colorectal cancer, among others (Table 1). The development of targeted therapy in NSCLC has changed the first-line treatment regimen for druggable mutation-positive patients: from platinum-based chemotherapy to targeted therapy in advanced and post-operative NSCLC [131-133]. The addition of rituximab to chemotherapy in CD20+ diffuse large B cell lymphoma significantly prolongs patients' DFS and OS [137]. However, the 'preciseness' in themselves are Achilles' heel to some extent: limited eligibility and resistance due to evolution of cancer cell population from sensitive to insensitive ones. For instance, 50\% of Asian patients and 10-15\% of Caucasian patients with lung adenocarcinoma are EGFR mutation-positive, with $5 \%$ of NSCLC being ALK positive and 1\% of NSCLC patients being ROS1 positive [138-140]. Moreover, treatment escalation by a newer generation of drugs is an inevitable but a rarely possible way, except for EGFR-mutated NSCLC, wherein acquired T790M mutation after administration of the first generation tyrosine kinase inhibitor (TKI) can be successfully targeted by osimertinib, the third generation TKI [141]. Additionally, therapies that target the growth of tumour blood vessels, rather than cancer cells are also available [142]. The signaling axis for angiogenesis consists of pro-angiogenetic molecules, corresponding receptors, and post-receptor signaling pathways, which jointly promote endothelial cell proliferation, migration, survival, and ultimately angiogenesis [143]. This cascade reaction can be inhibited at different levels, with Bevacizumab targeting vascular endothelial growth factor, Ramucirumab targeting vascular endothelial growth factor receptor-2, and TKI (cabozantinib, lapatinib, and sorafenib, to mention a few) targeting post-receptor signaling pathways. However, the major limitations for these strategies are the lower response rates, ranging between $2-30 \%$, rare 
but fatal complications like perforation and haemoptysis, and acquired resistance [143]. In addition, another group of drugs, namely vascular-disrupting agents (VDAs), can hinder the growth of cancer by either disrupting pre-existing blood vessels in cancer stroma or by having a direct cytotoxic effect on cancer cells [144]. However, current clinical trials have demonstrated its unsatisfactory competence in both single and combinatory settings for advanced cancers [145-147]. The bottleneck problem with VDAs appears to be incomplete tumour necrosis with remnant viable cancer cells that cause tumour regrowth. However, the new OncoCiDia strategy seems to be able to tackle such a bottleneck problem (see details in Section 5).

\subsection{The Contribution of and Concerns about Immunotherapy}

Lastly, immunotherapy, including cellular therapy, cytokines, or ICIs aims to treat cancers by increasing or restoring anticancer immunity (Table 1). Successful sporadic cure has been reported in chimeric antigen receptor T cells therapy and ICIs; however, the response rate is low, unpredictable, and vulnerable to other biological factors. The ICIs are gaining increasing popularity for their uniqueness in durable response and high response rates in some relapsed cancers. Ipilimumab, the first commercial monoclonal antibody targeting CTLA-4, was shown to offer a superior survival benefit for metastatic melanoma in 2011, compared with peptide or combinatory dacarbazine chemotherapy $[148,149]$. More strikingly, approximately $15 \%$ of patients showed a durable response more than 10 years after therapy discontinuation, which distinguishes immunotherapy from conventional therapies [150-152]. In addition, immunotherapy targeting the PD1/PDL1 axis has been receiving approval since 2014 for second-line or first-line therapies for an increasing number of malignancies, including melanoma, lymphoma, NSCLC, renal cell cancer, head and neck squamous cell cancer, bladder cancer, liver cancer, esophagogastric junction cancer, and micro-satellite unstable cancer of any origin $[153,154]$. The dual blockade by both CTLA4 and PD1/PDL1 yield improved survival in melanoma and NSCLC [134,155]. However, the response of ICIs varies among cancer types, with high response rates in melanoma, NSCLC, Hodgkin's lymphoma, Merkel cell carcinoma and microsatellite instability-high CRC, and with low response rate and marginal survival benefit in SCLC, renal cell carcinoma, and head and neck cancers [156]. More importantly, it is impossible to predict and identify patients that could potentially benefit from this therapy. Although biomarkers, including tumour mutation burden, programmed death ligand 1 (PD-L1) expression, lymphocyte infiltration rate, and tumour-immune phenotypes, were identified, their clinical efficacy for predicting treatment response remains unconfirmed and controversial $[157,158]$. Furthermore, the anticancer efficacy of ICIs is vulnerable to prior application of antibiotics, with significantly worse OS in patients receiving antibiotics (2 vs. 26 months) [159]. Additionally, hyperprogression is a deleterious effect of checkpoint inhibitors, characterized by accelerating cancer growth with an incidence rate of 9\% (12/131) [160]. More importantly, ICIs are associated with fatal toxicity effect in $0.3-1.3 \%$ patients, as reported more recently [161].

Table 1. Summary of the curative potential of currently available cancer therapeutics.

\begin{tabular}{|c|c|c|c|c|}
\hline Cancer Therapy * & Mechanism & Curative Potential & Example & Limitations \\
\hline \multicolumn{5}{|c|}{ Surgery } \\
\hline Open surgery & $\begin{array}{l}\text { Physical removal of cancer, } \\
\text { adjacent tissue, and } \\
\text { involved lymph nodes }\end{array}$ & $\begin{array}{l}\text { For early solid cancer, } \\
\qquad+++\end{array}$ & $\begin{array}{l}\text { Early NSCLC [162], HCC } \\
\text { [163], renal cancer [164] }\end{array}$ & $\begin{array}{l}\text { Surgical injury [165], cancer } \\
\text { dissemination [166] }\end{array}$ \\
\hline $\begin{array}{l}\text { Laparoscopic } \\
\text { surgery }\end{array}$ & Same as above & Same as above & Same as above & $\begin{array}{l}\text { Surgical injury [165], cancer } \\
\text { dissemination [166], } \\
\text { dependence of centralized } \\
\text { expert surgeons [53] }\end{array}$ \\
\hline Robotic surgery & Same as above & Same as above & $\begin{array}{c}\text { HCC [167], prostate cancer } \\
\text { [168] }\end{array}$ & $\begin{array}{l}\text { Same as above, imperfectly } \\
\text { confirmed efficacy }\end{array}$ \\
\hline $\begin{array}{l}\text { Endoscopic } \\
\text { surgery }\end{array}$ & Same as above & Same as above & Early GI cancer $[169,170]$ & $\begin{array}{l}\text { Possible second surgery [171], } \\
\text { perforation [172] }\end{array}$ \\
\hline
\end{tabular}


Table 1. Cont.

\begin{tabular}{|c|c|c|c|c|}
\hline Cancer Therapy * & Mechanism & Curative Potential & Example & Limitations \\
\hline \multicolumn{5}{|c|}{ Interventions } \\
\hline Ablations & $\begin{array}{l}\text { In situ necrotizing cancer } \\
\text { and adjacent tissue by local } \\
\text { hyperthermal ablation, } \\
\text { cryotherapy, or absolute } \\
\text { ethanol injection. }\end{array}$ & $\begin{array}{l}\text { For early eligible } \\
\text { cancer, }+++\end{array}$ & $\begin{array}{l}\text { HCC [173], renal cancer [174], } \\
\text { lung cancer [175] }\end{array}$ & $\begin{array}{c}\text { Often incomplete ablation } \\
\text { [176], injury to adjacent tissue } \\
{[177,178]}\end{array}$ \\
\hline \multicolumn{5}{|c|}{ Chemotherapy } \\
\hline Direct & $\begin{array}{l}\text { Alteration of DNA synthesis } \\
\text { and structure or } \\
\text { cytoskeleton }\end{array}$ & $\begin{array}{c}\text { For chemotherapy } \\
\text { sensitive cancer, }+++\end{array}$ & $\begin{array}{l}\text { Early lymphoma [180], ALL } \\
\text { [181], seminoma [182] }\end{array}$ & $\begin{array}{c}\text { Pancytopenia, nausea, } \\
\text { infertility, neuropathy [136], } \\
\text { secondary cancer [183] }\end{array}$ \\
\hline Radioiodine & $\begin{array}{l}\text { Same as above, for thyroid } \\
\text { cancer with iodine intake }\end{array}$ & $\begin{array}{c}\text { For thyroid cancer } \\
\text { with iodine intake, }++\end{array}$ & Thyroid cancer [108] & $\begin{array}{l}\text { Side-effects [190], secondary } \\
\text { cancer [109] }\end{array}$ \\
\hline $\begin{array}{l}\text { Radiopharmacy } \\
\text { (Lutetium 177) }\end{array}$ & Same as above & $-/+$ & NA & $\begin{array}{l}\text { Side-effects [191], secondary } \\
\text { cancer [192] }\end{array}$ \\
\hline Brachytherapy & Same as above & $-/+$ & NA & $\begin{array}{l}\text { Side-effects [193], secondary } \\
\text { cancer [194] }\end{array}$ \\
\hline \multicolumn{5}{|c|}{ Targeted therapy } \\
\hline Direct & $\begin{array}{l}\text { Inhibition of signaling } \\
\text { pathway, ADCC for } \\
\text { monoclonal antibody }\end{array}$ & $-/+$ & NA & $\begin{array}{c}\text { Acquired resistance [195]; } \\
\text { narrow spectrum of optimal } \\
\text { patients [196] }\end{array}$ \\
\hline $\begin{array}{c}\text { Cellular } \\
\text { immunotherapy }\end{array}$ & $\begin{array}{c}\text { Elimination of cancer cells } \\
\text { by immune cells with or } \\
\text { without engineering }\end{array}$ & $-/+$ & Leukemia [202] & $\begin{array}{l}\text { High cost [203], severe } \\
\text { side-effects [204] }\end{array}$ \\
\hline $\begin{array}{l}\text { Bone marrow } \\
\text { transplantation }\end{array}$ & $\begin{array}{l}\text { Elimination of cancer cells by } \\
\text { intensive chemotherapy and } \\
\text { graft-versus-leukemia effect }\end{array}$ & $\begin{array}{c}\text { Yes, for high-risk } \\
\text { haematological cancer } \\
{[205],+++}\end{array}$ & $\begin{array}{l}\text { Leukemia [206]; lymphoma } \\
\text { [207]; }\end{array}$ & $\begin{array}{l}\text { High mortality rate (5\%) [208] } \\
\text { and extensive } \\
\text { post-transplantation care [209] }\end{array}$ \\
\hline Endocrine therapy & $\begin{array}{l}\text { Inhabitation of growth by } \\
\text { altering hormone signaling }\end{array}$ & $\begin{array}{c}\text { Unknown \#, for } \\
\text { hormone receptor } \\
\text { positive patients, ++ }\end{array}$ & $\begin{array}{l}\text { Prostate cancer [210], breast } \\
\text { cancer [211] }\end{array}$ & Secondary cancer [212] \\
\hline
\end{tabular}

Abbreviations: ADCC: antibody-dependent cellular cytotoxicity; ALL: acute lymphoid leukemia; DNA: deoxyribonucleic acid; HCC: hepatocellular carcinoma; NSCLC: non-small cell lung cancer; NA: non-applicable; GI: gastrointestinal; ALL: acute lymphoid leukemia; NA: non-applicable; NPC: nasopharyngeal carcinoma; TACE: transarterial chemoembolization. * We refer to the therapies in each category with curative intention; ${ }^{*}$ hormone is often used in combinatory settings and therefore its role in single-use remains unclear. $-/+$ : unlikely but possible; +/-: possible but unlikely; + limited curative potential, only possible in some cases; ++ contribute to the cancer cure in combination; +++ with curative potential.

\section{Curability by Cancer Type and Stage}

To quantitatively show what we have achieved with the currently available diagnostic methods and treatments for different cancers, we present the stage distribution and corresponding five-year RSR in patients diagnosed in 2010 from the nine registries in the large population-based surveillance, epidemiology and end results (SEER) database [213]. Table 2 summarizes the curative potential by cancer type based on currently available therapeutics. To ensure the comparability and consistence of stage in different cancer types, we adopted the staging system provided in the SEER database, which contained three categories, including localized, regional, and distant. Here, localized cases refer to cancer lesion confined within its originated organ, with regional cases referring to cancer lesion spread 
to adjacent tissue (without metastasis) and distant cases referring to metastatic cases. Here, most patients were diagnosed at an advanced stage (regional or distant) in a majority of cancer types. Thus, early diagnosis by increased public awareness, widespread screening protocol, and development of more sensitive and discriminative detection methods may help change the scenario [214]. The prognosis varies among different cancer types with a five-year RSR of more than $80 \%$ in thyroid cancer, melanoma, breast cancer, and Hodgkin's lymphoma. However, the prognosis for SCLC, pancreatic cancer, HCC, oesophageal cancer, acute myeloid leukemia, NSCLC, and gastric cancer is still dismal, with a five-year RSR ranging between $7 \%$ and $28 \%$, emphasizing further endeavours in combating cancers (Figure 2). Some new drugs merely provide marginal survival benefit: 14 novel regimens approved for solid tumours by European Medicines Agency (EMA) are associated with a median OS benefit of 1.2 months, with a median OS benefit of 2.1 months for 48 new regimens approved by FDA between 2002 and $2014[215,216]$. It is estimated that development in treatment options explains only the $20 \%$ increase in five-year survival-from $49-68 \%$ over 40 years-whereas development in early diagnosis may have contributed much more [217-219]. Moreover, among 32 new drugs approved by EMA between 2014 and 2016 on the basis of 54 trials, only 10 randomized trials measured OS, with 19 randomized trials harbouring high risk of bias [220].

Table 2. Summary of curative potential by cancer type and stage based on currently available cancer therapeutics.

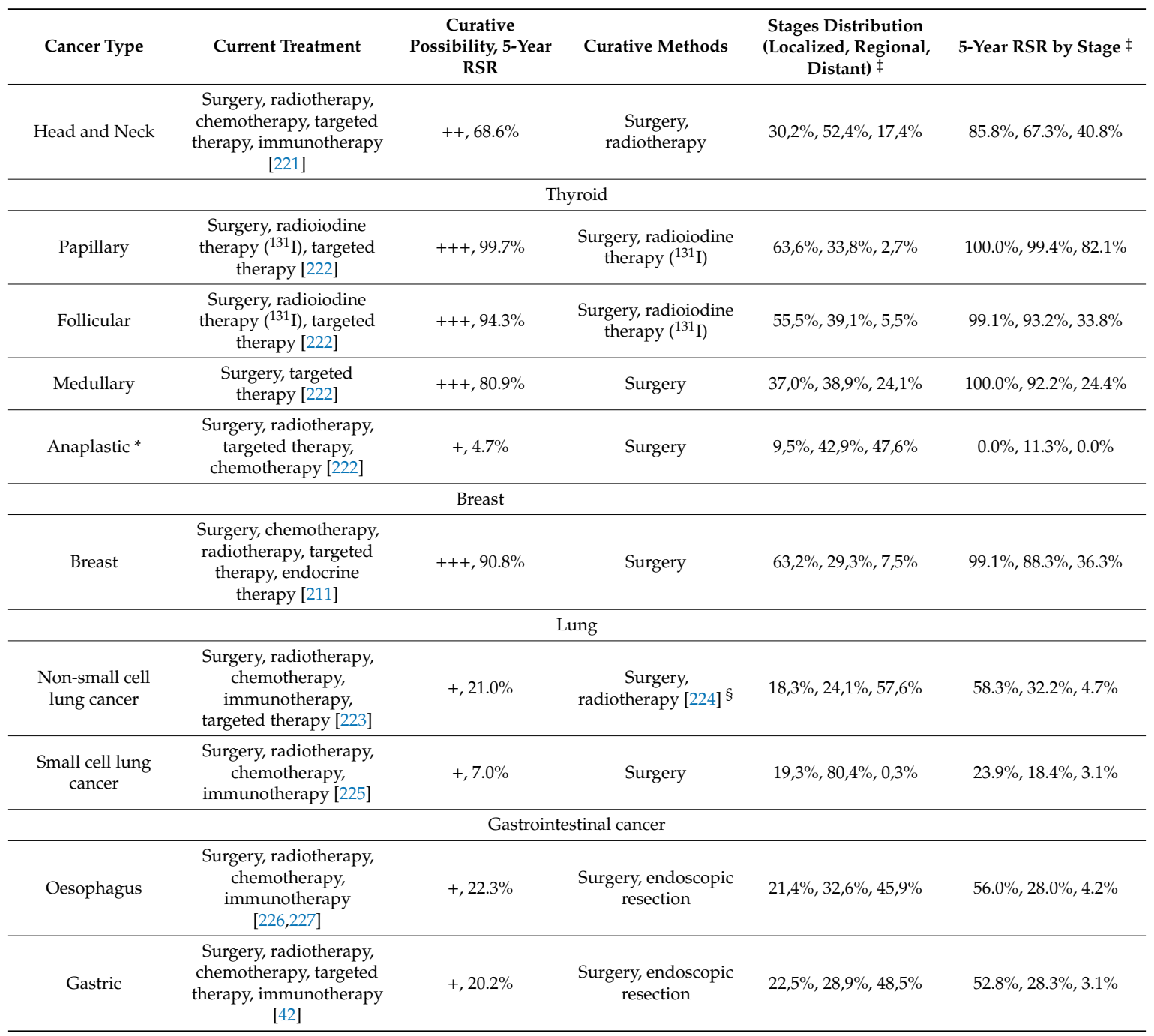


Table 2. Cont.

\begin{tabular}{|c|c|c|c|c|c|}
\hline Cancer Type & Current Treatment & $\begin{array}{c}\text { Curative } \\
\text { Possibility, 5-Year } \\
\text { RSR }\end{array}$ & Curative Methods & $\begin{array}{c}\text { Stages Distribution } \\
\text { (Localized, Regional, } \\
\text { Distant) } \ddagger\end{array}$ & 5-Year RSR by Stage $\ddagger$ \\
\hline \multicolumn{6}{|c|}{ Gastrointestinal cancer } \\
\hline Colorectal & $\begin{array}{l}\text { Surgery, chemotherapy, } \\
\text { targeted therapy, } \\
\text { radiotherapy, } \\
\text { immunotherapy [230] }\end{array}$ &,$++ 66.7 \%$ & $\begin{array}{l}\text { Surgery, endoscopic } \\
\text { resection }\end{array}$ & $42,6 \%, 35,6 \%, 21,7 \%$ & $90.2 \%, 75.0 \%, 13.6 \%$ \\
\hline \multicolumn{6}{|c|}{ Genitourinary cancer } \\
\hline Renal & $\begin{array}{l}\text { Surgery, chemotherapy, } \\
\text { targeted therapy, } \\
\text { immunotherapy, } \\
\text { ablation, radiotherapy } \\
\text { [232] }\end{array}$ &,$++ 74.6 \%$ & $\begin{array}{l}\text { Surgery, local } \\
\text { ablation }[174]^{\S}\end{array}$ & $0,2 \%, 51,8 \%, 48,0 \%$ & $92.9 \%, 70.0 \%, 11.4 \%$ \\
\hline Bladder & $\begin{array}{l}\text { Surgery, chemotherapy, } \\
\text { targeted therapy, } \\
\text { radiotherapy, } \\
\text { immunotherapy [233] }\end{array}$ &,$+++ 77.3 \%$ & Surgery & $0,3 \%, 77,9 \%, 21,8 \%$ & $90.8 \%, 44.9 \%, 3.7 \%$ \\
\hline \multicolumn{6}{|c|}{ Gynaecological cancer } \\
\hline Ovarian & $\begin{array}{l}\text { Surgery, chemotherapy, } \\
\text { radiotherapy, targeted } \\
\text { therapy, endocrine } \\
\text { therapy [235] }\end{array}$ &,$++ 46.8 \%$ & Surgery & $64,8 \%, 35,0 \% .0,2 \%$ & $95.0 \%, 62.8 \%, 31.7 \%$ \\
\hline Endometrial & $\begin{array}{l}\text { Surgery, chemotherapy, } \\
\text { radiotherapy, targeted } \\
\text { therapy, endocrine } \\
\text { therapy, immunotherapy } \\
\text { [236] }\end{array}$ &,$+++ 85.2 \%$ & Surgery & $0,3 \%, 63,0 \%, 36,7 \%$ & $96.5 \%, 71.6 \%, 32.5 \%$ \\
\hline Cervical & $\begin{array}{l}\text { Surgery, chemotherapy, } \\
\text { radiotherapy (EBRT, } \\
\text { brachytherapy), targeted } \\
\text { therapy, immunotherapy } \\
\text { [237] }\end{array}$ &,$++ 69.1 \%$ & Surgery & $48,5 \%, 36,6 \%, 14,9 \%$ & $92.4 \%, 60.9 \%, 18.0 \%$ \\
\hline & & Melanoma & & & \\
\hline Melanoma & $\begin{array}{l}\text { Surgery, chemotherapy, } \\
\text { radiotherapy, targeted } \\
\text { therapy, PDT, } \\
\text { immunotherapy [238] }\end{array}$ &,$+++ 93.7 \%$ & $\begin{array}{l}\text { Surgery, PDT, } \\
\text { immunotherapy }\end{array}$ & $0,7 \%, 68,6 \%, 30,7 \%$ & $99.4 \%, 68.3 \%, 17.9 \%$ \\
\hline \multicolumn{6}{|c|}{ Leukemia $^{\$}$} \\
\hline $\begin{array}{c}\text { Acute lymphoid } \\
\text { leukemia }\end{array}$ & $\begin{array}{c}\text { Chemotherapy, targeted } \\
\text { therapy, CAR-T, HSCT } \\
{[239,240]}\end{array}$ &,$++ 74.0 \%$ & $\begin{array}{l}\text { Chemotherapy, } \\
\text { HSCT }\end{array}$ & NA & NA \\
\hline
\end{tabular}


Table 2. Cont.

\begin{tabular}{|c|c|c|c|c|c|}
\hline Cancer Type & Current Treatment & $\begin{array}{c}\text { Curative } \\
\text { Possibility, 5-Year } \\
\text { RSR }\end{array}$ & Curative Methods & $\begin{array}{c}\text { Stages Distribution } \\
\text { (Localized, Regional, } \\
\text { Distant) } \ddagger\end{array}$ & 5-Year RSR by Stage $\ddagger$ \\
\hline \multicolumn{6}{|c|}{ Lymphoma $^{£}$} \\
\hline
\end{tabular}

Notes: Radiotherapy here refers to EBRT only, unless specified. Curative possibility (five-year RSR) scale: $+\longrightarrow<30 \%$; ++-30\%-75\%; +++->75\%. Abbreviations: RSR-relative survival rate; PDT-photodynamic therapy; HSCT—hematopoietic stem cell transplantation. $\ddagger$ All data here are accessed from the Surveillance, Epidemiology, and End Results (SEER) Program (www.seer.cancer.gov) SEER * Stat Database: Incidence—SEER 9 Regs Research Data, Nov 2018 Sub (1975-2016); The survival data by stage in anaplastic thyroid cancer is biased due to the few cases in each category. $\$$ Equivalent anticancer potential with surgery was only reported in retrospective studies but not in any randomized clinical trial. ${ }^{+}$Localized and regional prostate cancer cases together are merged as localized/regional cases. ${ }^{\$}$ All leukemia cases are categorized as distant cases and therefore stage distribution and corresponding survival information are blank. "II Patients with indolent cancer, based on a risk-stratification system, benefit more from active surveillance than any further intervention. ${ }^{£}$ Lymphoma is staged based on Ann Arbor staging system.
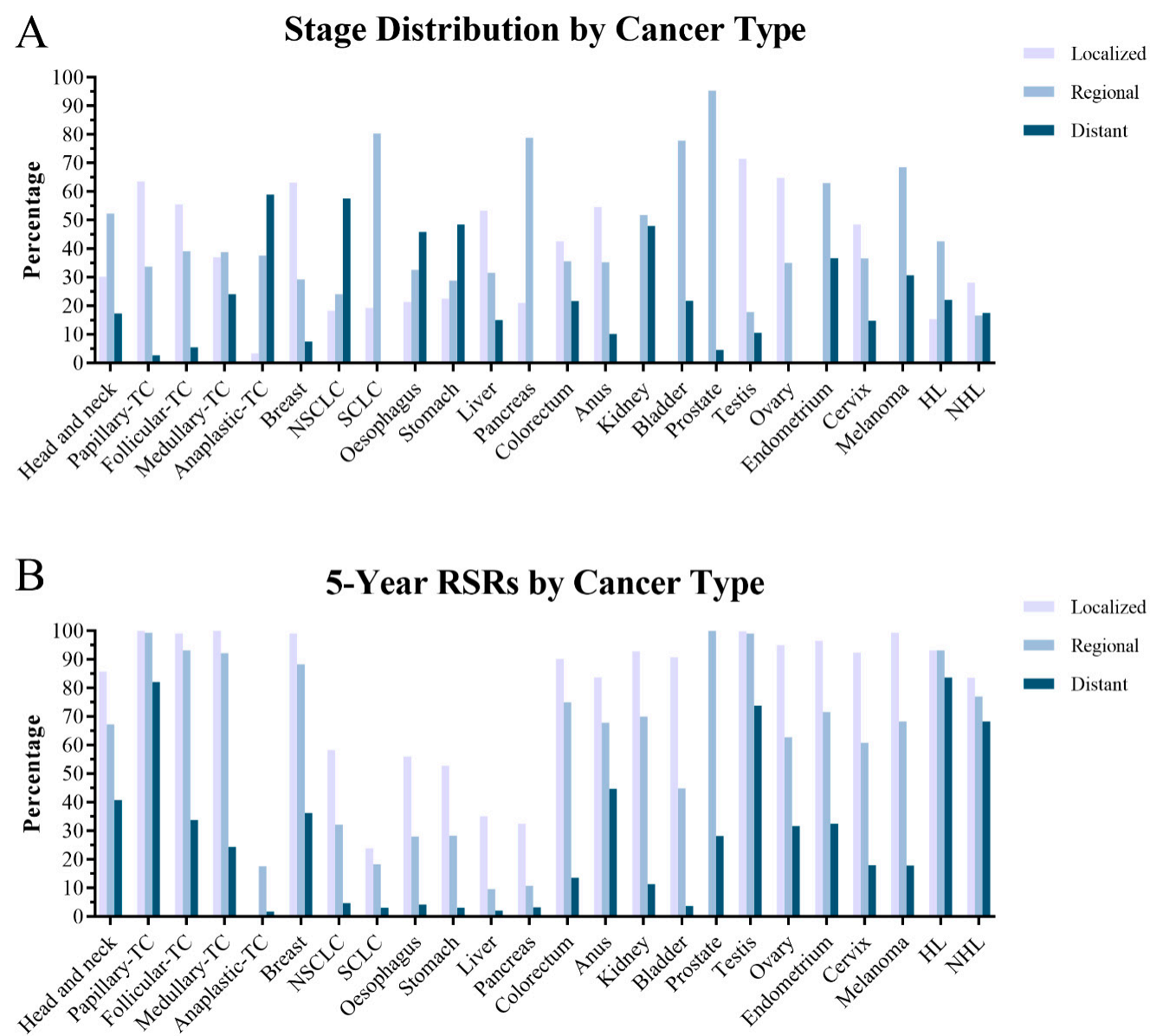

Figure 2. The distribution of stage (A) and corresponding five-year relative survival rates (B) by cancer types, based on cases diagnosed in 2010 in nine SEER registries. All data here are accessed from the Surveillance, Epidemiology, and End Results (SEER) Program (www.seer.cancer.gov) SEER*Stat Database: Incidence - SEER 9 Regs Research Data, November 2018 Sub (1975-2016). Note: Localized and regional prostate cancer cases are merged as localized/regional cases. 


\section{Cancer Screenings and Their Pros and Cons}

In parallel to the development of therapeutics, the development of screening also contributes to the improvement of cancer survival by promoting early diagnosis. Currently, the U.S. Preventive Services Task Force recommends screening in breast cancer by biennial mammogram for persons aged 50 and 74 years; cervical cancer by Pap test and/or HPV test for persons aged over 21 years; CRC by stool test, endoscopy or CT colonography for patients with aged between 50 and 75 years or earlier for high risk patients; and lung cancer by annual low dose CT for heavy smokers or persons aged between 55 and 80 years [245,246]. The goal of cancer screening is to achieve early diagnosis of cancer, which is destined to progress, and ultimately to prolong patients' survival by constantly emerging treatments. Screening in colon cancer and cervical cancer yields successful results, with a $70 \%$ reduction in mortality in cervical cancer and either $26 \%$ (data based on 155,000 patients from a USA trial) or $31 \%$ (data based on 170,000 patients from a UK trial) reduction in mortality in colon cancer [247-249].

However, screening may associate with overdiagnosis-detection of asymptomatic or indolent cancers that are not deemed to cause harm and therefore no active treatment is needed. Overdiagnosis is prevalent in breast cancer, prostate cancer, CRC, thyroid cancer, and melanoma [246,250-253]. The estimated overdiagnosis rate for breast cancer by mammography is $25 \%$, with $50-60 \%$ in prostate cancer by prostate-specific antigen (PSA), and 13-25\% in lung cancer by low-dose CT [254-256]. Mammography can detect more early-stage breast cancer but fails to induce commensurate incidence reduction in advanced disease as well as mortality in the population [251,252]. In addition, indolent breast tumours (slowly growing and estrogen-negative) are more easily detected by screening, a phenomenon termed length bias [257-259]. In terms of prostate cancer, screening by PSA is abandoned due to the high false-positive rate about $70 \%$ and a false negative rate of $15 \%$ [260-262]. Moreover, approximately half of the prostate cancer is indolent and silent, as it can be detected by autopsy in $36 \%$ of white men and $51 \%$ of black men who died from other causes [263,264]. In CRC, a surveillance study by colonography shows a diverse natural history of small polyps, with only $22 \%$ of them growing, $50 \%$ being stable, $28 \%$ shrinking, and $10 \%$ completely regressing [265]. Moreover, polyps were discovered in $32 \%$ of participants aged 60 years and more than $50 \%$ in older individuals from an international, population-based screening study, compared with the much lower risk of developing CRC (approximately 5\%) [266,267]. The futility of screening lies in cancer heterogeneity, i.e., not every tumour will ultimately progress or proceed at a pace rapid enough to ensure that early treatment can yield survival benefit during the limited life of a human. Thus, a more discriminative method based on a deeper understanding of cancer biology may better identify patients harbouring a rapidly-progressing tumour that necessitates timely treatment. Recently advocated high sensitivity liquid biopsy techniques are examples of such efforts [268-270].

\section{A Newly Proposed Broad-Spectrum Anti-Cancer Strategy Based on a Dual Stroma-Targeting Approach: Orchestrating with Liquid Biopsy}

Unlike therapies that are aimed at heterogeneous cancer cells, we developed a strategy called OncoCiDia, which targets cancer stroma components, which are more homogeneous and less mutational than cellular components [271]. The OncoCiDia strategy first applies a VDA that targets the misstructured endothelia of tumour blood vessels and induces massive (but never complete) ischemic tumour necrosis in virtually all solid cancers. However, following VDA injection, active angiogenesis and thereby cancer relapse are triggered due to cellular response to hypoxia, a pathophysiological phenomenon on which three winners shared the 2019 Nobel Prize for physiology and medicine [185]. To tackle this, in practice overnight after VDA administration, the patient is given radioactive ${ }^{131}$ I labeled necrosis-avid hypericin, which selectively sticks to the necrotic tumour site and constantly irradiates the remaining cancer cells using high-energy beta particles; meanwhile, the emitted gamma rays facilitate scintigraphy imaging. OncoCiDia represents a one-stop-shop theragnostic strategy: visualization, therapeutics, and monitoring radiation distribution, as compared to the ${ }^{177} \mathrm{Lu}$-Dotatate 
strategy, where a pretreatment PET scan is needed to identify optimal patients and predict treatment response [272,273]. A high percentage of the injected dose per gram of tissue (ID\%/g, median: 3.13\%; IQR: 2.92-3.97\%) of ${ }^{131}$ I-hypericin was observed in the tumour site eight days after injection, constituting a cumulative radiation dose of about $5000 \mathrm{~Gy}$, higher than that of antibody-based immunoradiotherapy with a concentration of $0.001-0.01 \%$ and a cumulative radiation dose of $15 \mathrm{~Gy}[271,274]$. Compared with ${ }^{177} \mathrm{Lu}$-Dotatate excreted via the kidney, excretion of ${ }^{131}$ I-hypericin by liver-bile duct-intestine, organs with a higher tolerance dose than that of the kidney, appears to be safer [275-279]. Moreover, targetability of OncoCiDia seems superior to that of ${ }^{177} \mathrm{Lu}$-Dotatate, which may go 'off target' in the kidney and spleen due to the expression of somatostatin receptors [271,280,281]. Currently, early phase clinical trials of OncoCiDia are ongoing in both veterinary and human patients [282,283].

OncoCiDia has a few unique features: First, it provides precise but wide-spectrum therapeutics, compared with conventional molecule-based targeted therapies that merely focus on patients with a druggable target. For instance, $17 \%$ of lung adenocarcinoma shows sensitive EGFR mutation, with $7 \%$ showing ALK mutation and 3\% showing MET mutation [223]. Moreover, mutation of ROS1, BRAF, RET, NTRK1, PIK3CA, and MEK1 occur in only $1 \%$ of lung adenocarcinoma [223]. More importantly, in eligible patients, due to cancer heterogeneity, cancer evolution (and subsequent resistance) ultimately occurs on shifting from a sensitive cell population to an insensitive one [284]. OncoCiDia, which targets the abnormal endothelia of tumour blood vessels, a target common to nearly all solid cancers, can substantially benefit more patients, and its efficacy is less likely affected by cellular heterogeneity. Second, OncoCiDia enables real-time monitoring of the accumulation of radiation in cancer lesions. Third, the cost of conventional targeted therapy is enormous, as a tiny proportion of eligible patients covers the cost for drug development. Forth, the response rate of conventional targeted therapy is modest in target-positive patients, with 47\% in HER-2 mutated gastric cancer [285], 71.2\% for gefitinib in EGFR-mutated NSCLC [133], 71\% for osimertinib for EGFR T790M mutated NSCLC [141], etc.

Besides, the curative potential of OncoCiDia in early cancers has been preliminarily implied by the successful induction of nearly complete necrosis by CA4P in primary [286] and secondary micro-cancers (Figure 3A). Here, we propose an updated hypothetical utility of OncoCiDia. If cancer can be detected at an early stage, i.e., micro-cancers of $2-5 \mathrm{~mm}$ in diameter undetectable by current imaging modalities but likely detectable by newly emerging supersensitive liquid biopsy techniques $[269,270]$, the remaining cancer cells after VDAs in such micro-cancers can be eradicated under the full coverage of beta radiation emitted by ${ }^{131}$ I with a $2 \mathrm{~mm}$ penetration distance (Figure $3 \mathrm{~B}$ ).

Liquid biopsy provides comprehensive information on the diagnosis, treatment response monitoring, and prognosis prediction by analyzing circulating tumour cells or cancer cell-derived fragments, especially DNA (ctDNA) [287]. With regard to early diagnosis, the CancerSEEK panel, incorporating detections of tumour biomarkers and ctDNA, achieves an overall median sensitivity of $70 \%$ and specificity of $\geq 99 \%$ in diagnosing cancers of the ovary, liver, stomach, pancreas, esophagus, colorectum, lung, and breast [268]. The sensitivity for stage I liver cancer is $100 \%$. Liquid biopsy on urine can empower early diagnosis of bladder cancer and recurrence surveillance $[288,289]$. In addition, liquid biopsy may also help identify minimal residual disease (MRD) in solid tumours before conventional imaging test does. MRD is a major resource for latent late recurrence, with $13 \%$ of T1N0 hormone receptor-positive breast cancer developing recurrence 20 years after therapy with curative intent [290]. In addition, recent reports have confirmed the metastasis of breast cancer and colorectal cancer even at earlier stages [270,291-293]; thus, OncoCiDia and liquid biopsy could synergistically play a role in such scenarios. This may open a new horizon for cancer management. 
A
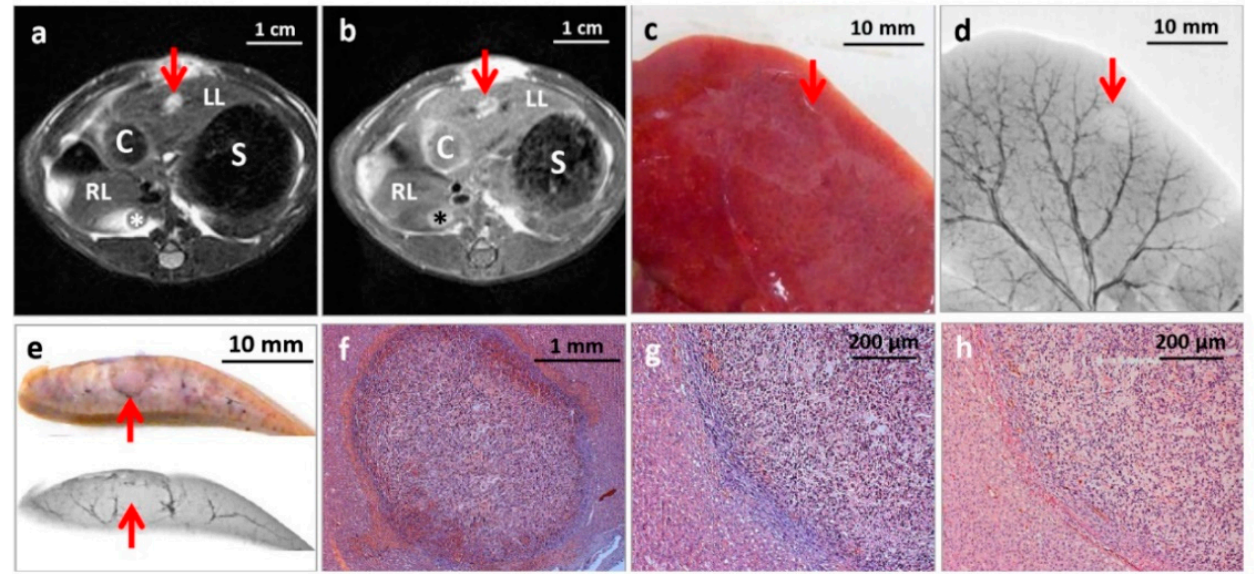

B
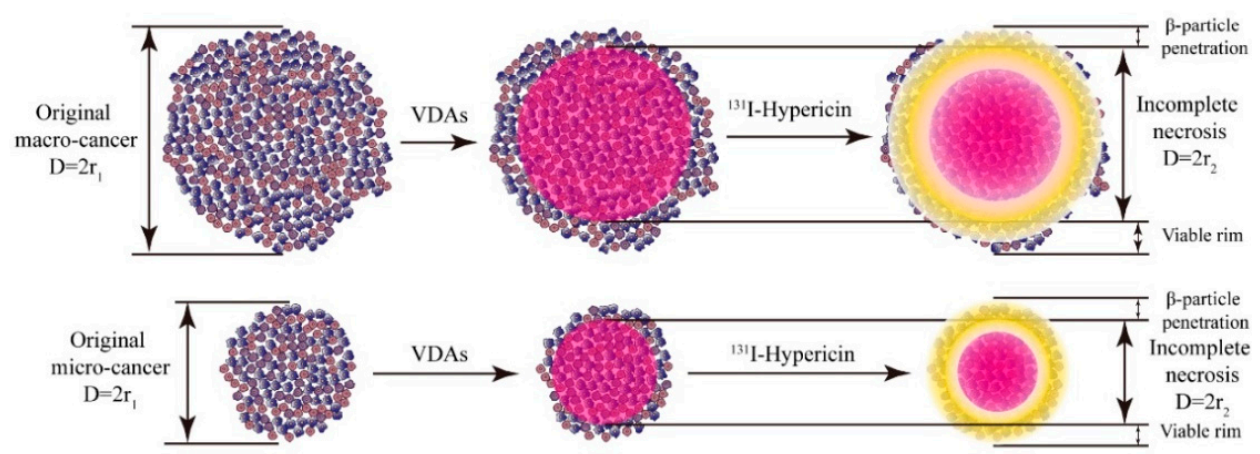

Assumptions : VDAs is believed to incudce $50-99 \%(\alpha)$ necrosis in tumor.

Formulae : The volume of the tumor with radius $r_{1}: V_{1}=\frac{4}{3} \pi r_{1}^{3}$; The volume for the necrotic tissue with radius $r_{2}: V_{2}=\frac{4}{3} \pi r_{2}^{3}$;

Suppose $\mathrm{V}_{2}=\mathrm{aV} \mathrm{V}_{1}$, that is $\frac{4}{3} \pi \mathrm{r}_{1}^{3}=\alpha \frac{4}{3} \pi \mathrm{r}_{2}^{3}$; Thus the thickness for viable rim $\delta=\mathrm{r}_{1}(1-\sqrt[3]{a})$.

Note : $\beta$ particle penetration is about $0.8-2.0 \mathrm{~mm}$ in depth, which should be greater than $\delta$ for curative effect.

Deduction : Only less than $10 \%$ of marco-cancers of 2-10 cm in diameter may achieve curative effect by one administration of OncoCiDia;

whereas, nearly all micro-cancer smaller than $2 \mathrm{~cm}$ in diameter can be cured by one administration of OncoCiDia.

Figure 3. (A) A representative example of rats with liver implantation of rhabdomyosarcoma (R1) $12 \mathrm{~h}$ after CA4P treatment. This micro R1 tumour measures $3.3 \mathrm{~mm}$ and $2.5 \mathrm{~mm}$ in long and short axis diameters, respectively. a: on T2 weighted transverse MRI, an oval hyperintense liver lesion (arrow) appears in the left liver lobe (LL); RL, right liver lobe; S, stomach; and C, colon. b: 15 min after contrast agent Gd-DOTA administration, left liver (LL) lesion is enhanced with a central dark region (arrow) suggestive of necrosis; RL, right liver lobe; S, stomach; and C, colon. c: liver specimen containing the micro R1 tumour (arrow) that is too small to be seen from the surface. $\mathrm{d}$ : corresponding microangiography shows the lesion as a filling defect suggestive of necrosis (arrow). e: the lesion (arrow) can be traced on the liver section (upper) and corresponding microangiography (bottom). f: low power HE stained microscopy reveals massive and partial hemorrhagic tumour necrosis with tissue reaction and possible tumour residues at the periphery of this virtually hypo- to avascular R1 tumour. g: higher power HE stained microscopy clearly depicts the central necrosis and peripheral few layers of viable R1 tumour cells without noticeable intratumoural vasculature. h: corresponding immunohistochemical CD34-PAS dual staining microscopy confirms the findings with HE staining. (B) A proposed curative OncoCiDia strategy with mathematical algorithms. In early-stage cancer, after the induction of nearly complete necrosis by systemic administration of a VDA, subsequently administered ${ }^{131}$ I labelled hypericin can precipitate in tumour necrosis and the emitted beta particles can fully cover the remaining cancer cells particularly in small solid malignancies or micro-cancers. The upper row simulates macro-cancers, with the lower row simulating micro-cancers. 


\section{Conclusions}

Over the past decades, great progress has been made in cancer diagnosis and therapeutics, which helps prolong survival in most cancer types. However, prognosis in some cancer types is still dismal and has only improved marginally over time. Therefore, early diagnosis is pivotal in improving the cure rate, and screening of the high-risk population seems to be a practical request. Given the ultra-sensitive characteristics and successfulness in detection of early cancer by liquid biopsy, the combinatory use of this method and the proposed OncoCiDia approach may be a non-invasive and curative or preventive strategy, particularly for patients with micro-cancers.

Author Contributions: Conceptualization, Y.N. \& Y.L. (Yue Li); Methodology, Y.L. (Yue Li) \& Y.N.; Publication research: S.W., Y.L. (Yewei Liu), Y.F. \& J.Z.; Writing-Original Draft Preparation, S.W., Y.F. \& Y.L. (Yewei Liu); Writing-Review \& Editing, Y.N. \& J.S.; Supervision, Y.N.; Project Administration, Y.N.; Funding Acquisition, Y.L. (Yue Li).

Funding: This work was partially supported by the National Natural Science Foundation of China (81771870 and 81603142) and a financial subsidy by Oncocidia Ltd., London, UK.

Acknowledgments: All authors gratefully acknowledge all personnel that contribute to the construction, maintenance and distribution of SEER data.

Conflicts of Interest: The authors declare no competing financial interests.

$\begin{array}{ll}\text { Abbreviations } \\ \text { ADCC } & \text { antibody-dependent cellular cytotoxicity } \\ \text { ALL } & \text { acute lymphoid leukemia } \\ \text { ALK } & \text { anaplastic lymphoma kinase } \\ \text { APC } & \text { antigen-presenting cell } \\ \text { CD } & \text { cluster of differentiation } \\ \text { CRC } & \text { colorectal cancer } \\ \text { CT } & \text { computed tomography } \\ \text { PET } & \text { positron emission tomography } \\ \text { CTLA-4 } & \text { cytotoxic T-lymphocyte-associated protein } 4 \\ \text { DFS } & \text { disease-free survival } \\ \text { DNA } & \text { deoxyribonucleic acid } \\ \text { EBRT } & \text { external beam radiotherapy } \\ \text { EGFR } & \text { epidermal growth factor receptor } \\ \text { EMA } & \text { European Medicines Agency } \\ \text { GI } & \text { gastrointestinal } \\ \text { HCC } & \text { hepatocellular carcinoma } \\ \text { HSCT } & \text { hematopoietic stem cell transplantation } \\ \text { ICIs } & \text { immune checkpoint inhibitors } \\ \text { IMRT } & \text { intensity-modulated radiation therapy } \\ \text { KRAS } & \text { Ki-ras2 Kirsten rat sarcoma viral oncogene homolog } \\ \text { MHC } & \text { major histocompatibility complex } \\ \text { MRD } & \text { minimal residual disease } \\ \text { NA } & \text { non-applicable } \\ \text { NCCN } & \text { national comprehensive cancer network } \\ \text { NP } & \text { nanoparticles } \\ \text { NPC } & \text { nasopharyngeal carcinoma } \\ \text { NSCLC } & \text { non-small cell lung cancer } \\ \text { OS } & \text { overall survival } \\ \text { PD-1 } & \text { programmed death 1 } \\ \text { PD-L1 } & \text { programmed death ligand 1 } \\ \text { PDT } & \text { photodynamic therapy } \\ \text { PFS } & \text { progression-free survival } \\ \text { PSA } & \text { prostate-specific antigen } \\ & \end{array}$




$\begin{array}{ll}\text { RAI } & \text { radioactive iodine } \\ \text { RECIST } & \text { response evaluation criteria in solid tumours } \\ \text { R1 } & \text { rhabdomyosarcoma } \\ \text { RSR } & \text { relative survival rate } \\ \text { SBRT } & \text { stereotactic body radiation therapy } \\ \text { SCLC } & \text { small cell lung cancer } \\ \text { SEER } & \text { surveillance, epidemiology and end results } \\ \text { TACE } & \text { transcatheter arterial chemoembolization } \\ \text { TCR } & \text { T cell receptor } \\ \text { TKI } & \text { tyrosine kinase inhibitor } \\ \text { TNM } & \text { tumour-node-metastasis } \\ \text { VDAs } & \text { vascular-disrupting agents }\end{array}$

\section{References}

1. Hanahan, D.; Weinberg, R.A. Hallmarks of cancer: The next generation. Cell 2011, 144, 646-674. [CrossRef] [PubMed]

2. Arruebo, M.; Vilaboa, N.; Sáez-Gutierrez, B.; Lambea, J.; Tres, A.; Valladares, M.; González-Fernández, A. Assessment of the evolution of cancer treatment therapies. Cancers 2011, 3, 3279-3330. [CrossRef] [PubMed]

3. Siegel, R.L.; Miller, K.D.; Jemal, A. Cancer statistics, 2019. CA Cancer J. Clin. 2019, 69, 7-34. [CrossRef] [PubMed]

4. Chen, W.; Zheng, R.; Baade, P.D.; Zhang, S.; Zeng, H.; Bray, F.; Jemal, A.; Yu, X.Q.; He, J. Cancer statistics in China, 2015. CA Cancer J. Clin. 2016, 66, 115-132. [CrossRef] [PubMed]

5. Barlas, S. The White House Launches a Cancer Moonshot: Despite Funding Questions, the Progress Appears Promising. Pharm. Ther. 2016, 41, 290-295.

6. Sun, T.; Wang, S.; Sun, H.; Wen, J.; An, G.; Li, J. Improved survival in multiple myeloma, with a diminishing racial gap and a widening socioeconomic status gap over three decades. Leuk. Lymphoma 2018, 59, 49-58. [CrossRef]

7. Lu, G.; Li, J.; Wang, S.; Pu, J.; Sun, H.; Wei, Z.; Ma, Y.; Wang, J.; Ma, H. The fluctuating incidence, improved survival of patients with breast cancer, and disparities by age, race, and socioeconomic status by decade, 1981-2010. Cancer Manag. Res. 2018, 10, 4899-4914. [CrossRef]

8. Wang, S.; Sun, H.; Xie, Z.; Li, J.; Hong, G.; Li, D.; Mallampati, S.; Zhou, X.; Zhou, C.; Zhang, H.; et al. Improved survival of patients with hepatocellular carcinoma and disparities by age, race, and socioeconomic status by decade, 1983-2012. Oncotarget 2016, 7, 59820-59833. [CrossRef]

9. Wang, S.; Tang, J.; Sun, T.; Zheng, X.; Li, J.; Sun, H.; Zhou, X.; Zhou, C.; Zhang, H.; Cheng, Z.; et al. Survival changes in patients with small cell lung cancer and disparities between different sexes, socioeconomic statuses and ages. Sci. Rep. 2017, 7, 1339. [CrossRef]

10. Wang, S.; Song, R.; Sun, T.; Hou, B.; Hong, G.; Mallampati, S.; Sun, H.; Zhou, X.; Zhou, C.; Zhang, H.; et al. Survival changes in Patients with Synovial Sarcoma, 1983-2012. J. Cancer 2017, 8, 1759-1768. [CrossRef]

11. Kroemer, G.; Galluzzi, L.; Vandenabeele, P.; Abrams, J.; Alnemri, E.S.; Baehrecke, E.H.; Blagosklonny, M.V.; El-Deiry, W.S.; Golstein, P.; Green, D.R.; et al. Classification of cell death: Recommendations of the Nomenclature Committee on Cell Death 2009. Cell Death Differ. 2009, 16, 3-11. [CrossRef] [PubMed]

12. Makin, G.; Hickman, J.A. Apoptosis and cancer chemotherapy. Cell Tissue Res. 2000, 301, 143-152. [CrossRef] [PubMed]

13. Balcer-Kubiczek, E.K. Apoptosis in radiation therapy: A double-edged sword. Exp. Oncol. 2012, 34, $277-285$. [PubMed]

14. Denisenko, T.V.; Sorokina, I.V.; Gogvadze, V.; Zhivotovsky, B. Mitotic catastrophe and cancer drug resistance: A link that must to be broken. Drug Resist. Updates 2016, 24, 1-12. [CrossRef] [PubMed]

15. Kaidar-Person, O.; Zagar, T.M.; Deal, A.; Moschos, S.J.; Ewend, M.G.; Sasaki-Adams, D.; Lee, C.B.; Collichio, F.A.; Fried, D.; Marks, L.B.; et al. The incidence of radiation necrosis following stereotactic radiotherapy for melanoma brain metastases: The potential impact of immunotherapy. Anti Cancer Drugs 2017, 28, 669-675. [CrossRef] [PubMed] 
16. Samimi, M.A.; Mirkheshti, N.; Pazouki, A. Assessing the percent of necrosis after neoadjuvant chemotherapy with $24 \mathrm{hr}$ infusional cisplatin/3 days Doxorubicin intermittent with Ifosfamide-Doxorubicin for osteosarcoma. Int. J. Hematol. Oncol. Stem Cell Res. 2014, 8, 5-8. [PubMed]

17. Picci, P.; Bacci, G.; Campanacci, M.; Gasparini, M.; Pilotti, S.; Cerasoli, S.; Bertoni, F.; Guerra, A.; Capanna, R.; Albisinni, U.; et al. Histologic evaluation of necrosis in osteosarcoma induced by chemotherapy. Regional mapping of viable and nonviable tumor. Cancer 1985, 56, 1515-1521. [CrossRef]

18. Varzaneh, F.N.; Pandey, A.; Ghasabeh, M.A.; Shao, N.; Khoshpouri, P.; Pandey, P.; Zarghampour, M.; Fouladi, D.; Liddell, R.; Anders, R.A.; et al. Prediction of post-TACE necrosis of hepatocellular carcinoma usingvolumetric enhancement on MRI and volumetric oil deposition on CT, with pathological correlation. Eur. Radiol. 2018, 28, 3032-3040. [CrossRef]

19. Sellers, A.H. The clinical classification of malignant tumours: The TNM system. Can. Med. Assoc. J. 1971, 105,836 .

20. Trakarnsanga, A.; Ithimakin, S.; Weiser, M.R. Treatment of locally advanced rectal cancer: Controversies and questions. World J. Gastroenterol. 2012, 18, 5521-5532. [CrossRef]

21. Rosenzweig, K.E.; Gomez, J.E. Concurrent Chemotherapy and Radiation Therapy for Inoperable Locally Advanced Non-Small-Cell Lung Cancer. J. Clin. Oncol. 2017, 35, 6-10. [CrossRef] [PubMed]

22. Smith, J.J.; Garcia-Aguilar, J. Advances and challenges in treatment of locally advanced rectal cancer. J. Clin. Oncol. 2015, 33, 1797-1808. [CrossRef] [PubMed]

23. Kurnick, J.E.; Robinson, W.A. Cell kill hypothesis. Arch. Intern. Med. 1972, 130, 790. [CrossRef] [PubMed]

24. Miller, K.; Abraham, J.H.; Rhodes, L.; Roberts, R. Use of the word "cure" in oncology. J. Oncol. Pract. 2013, 9, 136-140. [CrossRef] [PubMed]

25. Trad, D.; Bibani, N.; Sabbah, M.; Elloumi, H.; Gargouri, D.; Ouakaa, A.; Kharrat, J. Known, new and emerging risk factors of hepatocellular carcinoma (review). Presse Med. 2017, 46, 1000-1007. [CrossRef] [PubMed]

26. Siegel, R.L.; Miller, K.D.; Jemal, A. Cancer statistics, 2015. CA Cancer J. Clin. 2015, 65, 5-29. [CrossRef]

27. Pazdur, R. Endpoints for assessing drug activity in clinical trials. Oncologist 2008, 13, 19-21. [CrossRef]

28. Oba, K.; Paoletti, X.; Alberts, S.; Bang, Y.J.; Benedetti, J.; Bleiberg, H.; Catalano, P.; Lordick, F.; Michiels, S.; Morita, S.; et al. Disease-free survival as a surrogate for overall survival in adjuvant trials of gastric cancer: A meta-analysis. J. Natl. Cancer Inst. 2013, 105, 1600-1607. [CrossRef]

29. Blumenthal, G.M.; Karuri, S.W.; Zhang, H.; Zhang, L.; Khozin, S.; Kazandjian, D.; Tang, S.; Sridhara, R.; Keegan, P.; Pazdur, R. Overall response rate, progression-free survival, and overall survival with targeted and standard therapies in advanced non-small-cell lung cancer: US Food and Drug Administration trial-level and patient-level analyses. J. Clin. Oncol. 2015, 33, 1008-1014. [CrossRef]

30. Eisenhauer, E.A.; Therasse, P.; Bogaerts, J.; Schwartz, L.H.; Sargent, D.; Ford, R.; Dancey, J.; Arbuck, S.; Gwyther, S.; Mooney, M.; et al. New response evaluation criteria in solid tumours: Revised RECIST guideline (version 1.1). Eur. J. Cancer 2009, 45, 228-247. [CrossRef]

31. Seymour, L.; Bogaerts, J.; Perrone, A.; Ford, R.; Schwartz, L.H.; Mandrekar, S.; Lin, N.U.; Litiere, S.; Dancey, J.; Chen, A.; et al. iRECIST: Guidelines for response criteria for use in trials testing immunotherapeutics. Lancet Oncol. 2017, 18, 143-152. [CrossRef]

32. Mariotto, A.B.; Noone, A.-M.; Howlader, N.; Cho, H.; Keel, G.E.; Garshell, J.; Woloshin, S.; Schwartz, L.M. Cancer survival: An overview of measures, uses, and interpretation. J. Natl. Cancer Inst. Monogr. 2014, 2014, 145-186. [CrossRef] [PubMed]

33. Henson, D.E.; Ries, L.A. The relative survival rate. Cancer 1995, 76, 1687-1688. [CrossRef]

34. Makkar, N.; Ostrom, Q.T.; Kruchko, C.; Barnholtz-Sloan, J.S. A comparison of relative survival and cause-specific survival methods to measure net survival in cancer populations. Cancer Med. 2018, 7, 4773-4780. [CrossRef] [PubMed]

35. Mok, T.S.K.; Wu, Y.-L.; Kudaba, I.; Kowalski, D.M.; Cho, B.C.; Turna, H.Z.; Castro, G.; Srimuninnimit, V.; Laktionov, K.K.; Bondarenko, I.; et al. Pembrolizumab versus chemotherapy for previously untreated, PD-L1-expressing, locally advanced or metastatic non-small-cell lung cancer (KEYNOTE-042): A randomised, open-label, controlled, phase 3 trial. Lancet 2019, 393, 1819-1830. [CrossRef]

36. Armitage, J.O.; Gascoyne, R.D.; Lunning, M.A.; Cavalli, F. Non-Hodgkin lymphoma. Lancet 2017, 390, 298-310. [CrossRef]

37. Shanbhag, S.; Ambinder, R.F. Hodgkin lymphoma: A review and update on recent progress. CA Cancer J. Clin. 2018, 68, 116-132. [CrossRef] 
38. Hamilton, J.P.; Sato, F.; Greenwald, B.D.; Suntharalingam, M.; Krasna, M.J.; Edelman, M.J.; Doyle, A.; Berki, A.T.; Abraham, J.M.; Mori, Y.; et al. Promoter methylation and response to chemotherapy and radiation in esophageal cancer. Clin. Gastroenterol. Hepatol. 2006, 4, 701-708. [CrossRef]

39. Sullivan, R.; Alatise, O.I.; Anderson, B.O.; Audisio, R.; Autier, P.; Aggarwal, A.; Balch, C.; Brennan, M.F.; Dare, A.; D'Cruz, A.; et al. Global cancer surgery: Delivering safe, affordable, and timely cancer surgery. Lancet Oncol. 2015, 16, 1193-1224. [CrossRef]

40. Zeng, Y.K.; Yang, Z.L.; Peng, J.S.; Lin, H.S.; Cai, L. Laparoscopy-assisted versus open distal gastrectomy for early gastric cancer: Evidence from randomized and nonrandomized clinical trials. Ann. Surg. 2012, 256, 39-52. [CrossRef]

41. Choi, Y.Y.; Bae, J.M.; An, J.Y.; Hyung, W.J.; Noh, S.H. Laparoscopic gastrectomy for advanced gastric cancer: Are the long-term results comparable with conventional open gastrectomy? A systematic review and meta-analysis. J. Surg. Oncol. 2013, 108, 550-556. [CrossRef] [PubMed]

42. Van Cutsem, E.; Sagaert, X.; Topal, B.; Haustermans, K.; Prenen, H. Gastric cancer. Lancet 2016, 388, $2654-2664$. [CrossRef]

43. Melamed, A.; Margul, D.J.; Chen, L.; Keating, N.L.; del Carmen, M.G.; Yang, J.; Seagle, B.-L.L.; Alexander, A.; Barber, E.L.; Rice, L.W.; et al. Survival after Minimally Invasive Radical Hysterectomy for Early-Stage Cervical Cancer. N. Engl. J. Med. 2018, 379, 1905-1914. [CrossRef] [PubMed]

44. Strobel, O.; Büchler, M.W. Laparoscopic pancreatoduodenectomy: Safety concerns and no benefits. Lancet Gastroenterol. Hepatol. 2019, 4, 186-187. [CrossRef]

45. van Hilst, J.; de Rooij, T.; Bosscha, K.; Brinkman, D.J.; van Dieren, S.; Dijkgraaf, M.G.; Gerhards, M.F.; de Hingh, I.H.; Karsten, T.M.; Lips, D.J.; et al. Laparoscopic versus open pancreatoduodenectomy for pancreatic or periampullary tumours (LEOPARD-2): A multicentre, patient-blinded, randomised controlled phase 2/3 trial. Lancet. Gastroenterol. Hepatol. 2019, 4, 199-207. [CrossRef]

46. Ramirez, P.T.; Frumovitz, M.; Pareja, R.; Lopez, A.; Vieira, M.; Ribeiro, R.; Buda, A.; Yan, X.; Shuzhong, Y.; Chetty, N.; et al. Minimally Invasive versus Abdominal Radical Hysterectomy for Cervical Cancer. N. Engl. J. Med. 2018, 379, 1895-1904. [CrossRef]

47. Belderbos, T.D.; van Erning, F.N.; de Hingh, I.H.; van Oijen, M.G.; Lemmens, V.E.; Siersema, P.D. Long-term Recurrence-free Survival After Standard Endoscopic Resection Versus Surgical Resection of Submucosal Invasive Colorectal Cancer: A Population-based Study. Clin. Gastroenterol. Hepatol. 2017, 15, 403-411. [CrossRef]

48. Heo, J.; Jeon, S.W.; Jung, M.K.; Kim, S.K.; Kim, J.; Kim, S. Endoscopic resection as the first-line treatment for early colorectal cancer: Comparison with surgery. Surg. Endosc. 2014, 28, 3435-3442. [CrossRef]

49. Pyo, J.H.; Lee, H.; Min, B.H.; Lee, J.H.; Choi, M.G.; Lee, J.H.; Sohn, T.S.; Bae, J.M.; Kim, K.M.; Ahn, J.H.; et al. Long-Term Outcome of Endoscopic Resection vs. Surgery for Early Gastric Cancer: A Non-inferiority-Matched Cohort Study. Am.J. Gastroenterol. 2016, 111, 240-249. [CrossRef]

50. Das, A.; Singh, V.; Fleischer, D.E.; Sharma, V.K. A comparison of endoscopic treatment and surgery in early esophageal cancer: An analysis of surveillance epidemiology and end results data. Am.J. Gastroenterol. 2008, 103, 1340-1345. [CrossRef]

51. Sheetz, K.H.; Dimick, J.B. Is It Time for Safeguards in the Adoption of Robotic Surgery. JAMA 2019, 321, 1971-1972. [CrossRef] [PubMed]

52. Administration, U.F.a.D. Caution When Using Robotically-Assisted Surgical Devices in Women's Health Including Mastectomy and Other Cancer-Related Surgeries: FDA Safety Communication. Available online: https://www.fda.gov/medicaldevices/safety/alertsandnotices/ucm632142.htm (accessed on 7 November 2019).

53. Adam, M.A.; Thomas, S.; Youngwirth, L.; Pappas, T.; Roman, S.A.; Sosa, J.A. Defining a Hospital Volume Threshold for Minimally Invasive Pancreaticoduodenectomy in the United States. JAMA Surg. 2017, 152, 336-342. [CrossRef] [PubMed]

54. Hayn, M.H.; Hussain, A.; Mansour, A.M.; Andrews, P.E.; Carpentier, P.; Castle, E.; Dasgupta, P.; Rimington, P.; Thomas, R.; Khan, S.; et al. The learning curve of robot-assisted radical cystectomy: Results from the International Robotic Cystectomy Consortium. Eur. Urol. 2010, 58, 197-202. [CrossRef] [PubMed]

55. Bolenz, C.; Freedland, S.J.; Hollenbeck, B.K.; Lotan, Y.; Lowrance, W.T.; Nelson, J.B.; Hu, J.C. Costs of radical prostatectomy for prostate cancer: A systematic review. Eur. Urol. 2014, 65, 316-324. [CrossRef]

56. Boutros, J.; Bond, M.; Beaudry, P.; Blair, G.K.; Skarsgard, E.D. Case selection in minimally invasive surgical treatment of neuroblastoma. Pediatr. Surg. Int. 2008, 24, 1177-1180. [CrossRef] 
57. Mulier, S.; Mulier, P.; Ni, Y.; Miao, Y.; Dupas, B.; Marchal, G.; De Wever, I.; Michel, L. Complications of radiofrequency coagulation of liver tumours. Br. J. Surg. 2002, 89, 1206-1222. [CrossRef]

58. Jahangeer, S.; Forde, P.; Soden, D.; Hinchion, J. Review of current thermal ablation treatment for lung cancer and the potential of electrochemotherapy as a means for treatment of lung tumours. Cancer Treat. Rev. 2013, 39, 862-871. [CrossRef]

59. Ni, Y.; Mulier, S.; Miao, Y.; Michel, L.; Marchal, G. A review of the general aspects of radiofrequency ablation. Abdom. Imaging 2005, 30, 381-400. [CrossRef]

60. Finn, R.S.; Zhu, A.X.; Farah, W.; Almasri, J.; Zaiem, F.; Prokop, L.J.; Murad, M.H.; Mohammed, K. Therapies for advanced stage hepatocellular carcinoma with macrovascular invasion or metastatic disease: A systematic review and meta-analysis. Hepatology 2018, 67, 422-435. [CrossRef]

61. Sieghart, W.; Hucke, F.; Peck-Radosavljevic, M. Transarterial chemoembolization: Modalities, indication, and patient selection. J. Hepatol. 2015, 62, 1187-1195. [CrossRef]

62. Delaney, G.; Jacob, S.; Featherstone, C.; Barton, M. The role of radiotherapy in cancer treatment. Cancer 2005, 104, 1129-1137. [CrossRef] [PubMed]

63. Chen, H.H.W.; Kuo, M.T. Improving radiotherapy in cancer treatment: Promises and challenges. Oncotarget 2017, 8, 62742-62758. [CrossRef] [PubMed]

64. Mehta, S.R.; Suhag, V.; Semwal, M.; Sharma, N. Radiotherapy: Basic Concepts and Recent Advances. Med. J. Armed Forces India 2010, 66, 158-162. [CrossRef]

65. Reference, M.D. Definition for Heavy Ion. Available online: http://www.reference.md/files/D020/mD020450. html (accessed on 7 November 2019).

66. Palm, A.; Johansson, K.A. A review of the impact of photon and proton external beam radiotherapy treatment modalities on the dose distribution in field and out-of-field; implications for the long-term morbidity of cancer survivors. Acta Oncol. 2007, 46, 462-473. [CrossRef]

67. Kokurewicz, K.; Brunetti, E.; Welsh, G.H.; Wiggins, S.M.; Boyd, M.; Sorensen, A.; Chalmers, A.J.; Schettino, G.; Subiel, A.; DesRosiers, C.; et al. Focused very high-energy electron beams as a novel radiotherapy modality for producing high-dose volumetric elements. Sci. Rep. 2019, 9, 10837. [CrossRef]

68. Higgins, K.A.; O'Connell, K.; Liu, Y.; Gillespie, T.W.; McDonald, M.W.; Pillai, R.N.; Patel, K.R.; Patel, P.R.; Robinson, C.G.; Simone, C.B., 2nd; et al. National Cancer Database Analysis of Proton Versus Photon Radiation Therapy in Non-Small Cell Lung Cancer. Int. J. Radiat. Oncol. Biol. Phys. 2017, 97, 128-137. [CrossRef]

69. Jermann, M. Particle Therapy Statistics in 2014. Int. J. Part. Ther. 2015, 2, 50-54. [CrossRef]

70. Group, P.T.C.-O. Particle Therapy Patient Statistics (per End of 2016). Available online: https://www.ptcog. ch/archive/patient_statistics/Patientstatistics-updateDec2016.pdf (accessed on 7 November 2019).

71. Mohan, R.; Grosshans, D. Proton therapy-Present and future. Adv. Drug Deliv. Rev. 2017, 109, $26-44$. [CrossRef]

72. Thomas, J.; Ferme, C.; Noordijk, E.M.; Morschhauser, F.; Girinsky, T.; Gaillard, I.; Lugtenburg, P.J.; Andre, M.; Lybeert, M.L.M.; Stamatoullas, A.; et al. Comparison of 36 Gy, 20 Gy, or No Radiation Therapy After 6 Cycles of EBVP Chemotherapy and Complete Remission in Early-Stage Hodgkin Lymphoma Without Risk Factors: Results of the EORT-GELA H9-F Intergroup Randomized Trial. Int. J. Radiat. Oncol. Biol. Phys. 2018, 100, 1133-1145. [CrossRef]

73. Ramroth, J.; Cutter, D.J.; Darby, S.C.; Higgins, G.S.; McGale, P.; Partridge, M.; Taylor, C.W. Dose and Fractionation in Radiation Therapy of Curative Intent for Non-Small Cell Lung Cancer: Meta-Analysis of Randomized Trials. Int. J. Radiat. Oncol. Biol. Phys. 2016, 96, 736-747. [CrossRef]

74. Bradley, J.; Thorstad, W.L.; Mutic, S.; Miller, T.R.; Dehdashti, F.; Siegel, B.A.; Bosch, W.; Bertrand, R.J. Impact of FDG-PET on radiation therapy volume delineation in non-small-cell lung cancer. Int. J. Radiat. Oncol. Biol. Phys. 2004, 59, 78-86. [CrossRef] [PubMed]

75. Keall, P.J.; Nguyen, D.T.; O’Brien, R.; Zhang, P.; Happersett, L.; Bertholet, J.; Poulsen, P.R. Review of Real-Time 3-Dimensional Image Guided Radiation Therapy on Standard-Equipped Cancer Radiation Therapy Systems: Are We at the Tipping Point for the Era of Real-Time Radiation Therapy. Int. J. Radiat. Oncol. Biol. Phys. 2018, 102, 922-931. [CrossRef] [PubMed]

76. Jimenez, R.B.; Hickey, S.; DePauw, N.; Yeap, B.Y.; Batin, E.; Gadd, M.A.; Specht, M.; Isakoff, S.J.; Smith, B.L.; Liao, E.C.; et al. Phase II Study of Proton Beam Radiation Therapy for Patients With Breast Cancer Requiring Regional Nodal Irradiation. J. Clin. Oncol. 2019, 37, 2778-2785. [CrossRef] [PubMed] 
77. Pan, H.Y.; Jiang, J.; Hoffman, K.E.; Tang, C.; Choi, S.L.; Nguyen, Q.N.; Frank, S.J.; Anscher, M.S.; Shih, Y.T.; Smith, B.D. Comparative Toxicities and Cost of Intensity-Modulated Radiotherapy, Proton Radiation, and Stereotactic Body Radiotherapy Among Younger Men With Prostate Cancer. J. Clin. Oncol. 2018, 36, 1823-1830. [CrossRef] [PubMed]

78. Brown, J.M.; Carlson, D.J.; Brenner, D.J. The Tumor Radiobiology of SRS and SBRT: Are More Than the 5 Rs Involved. Int. J. Radiat. Oncol. Biol. Phys. 2014, 88, 254-262. [CrossRef] [PubMed]

79. Chaudhuri, A.A.; Tang, C.; Binkley, M.S.; Jin, M.; Wynne, J.F.; von Eyben, R.; Hara, W.Y.; Trakul, N.; Loo, B.W.; Diehn, M. Stereotactic ablative radiotherapy (SABR) for treatment of central and ultra-central lung tumors. Lung Cancer 2015, 89, 50-56. [CrossRef]

80. Palma, D.; Daly, M.; Urbanic, J.; Giuliani, M. Stereotactic Radiation for Ultra-Central Lung Tumors: Good Idea, or Ultra-Risky. Int. J. Radiat. Oncol. Biol. Phys. 2019, 103, 788-791. [CrossRef]

81. Bezjak, A.; Paulus, R.; Gaspar, L.E.; Timmerman, R.D.; Straube, W.L.; Ryan, W.F.; Garces, Y.I.; Pu, A.T.; Singh, A.K.; Videtic, G.M.; et al. Safety and Efficacy of a Five-Fraction Stereotactic Body Radiotherapy Schedule for Centrally Located Non-Small-Cell Lung Cancer: NRG Oncology/RTOG 0813 Trial. J. Clin. Oncol. 2019, 37, 1316-1325. [CrossRef]

82. Timmerman, R.; McGarry, R.; Yiannoutsos, C.; Papiez, L.; Tudor, K.; DeLuca, J.; Ewing, M.; Abdulrahman, R.; DesRosiers, C.; Williams, M.; et al. Excessive toxicity when treating central tumors in a phase II study of stereotactic body radiation therapy for medically inoperable early-stage lung cancer. J. Clin. Oncol. 2006, 24, 4833-4839. [CrossRef]

83. Chicas-Sett, R.; Morales-Orue, I.; Castilla-Martinez, J.; Zafra-Martin, J.; Kannemann, A.; Blanco, J.; Lloret, M.; Lara, P.C. Stereotactic Ablative Radiotherapy Combined with Immune Checkpoint Inhibitors Reboots the Immune Response Assisted by Immunotherapy in Metastatic Lung Cancer: A Systematic Review. Int. J. Mol. Sci. 2019, 20. [CrossRef]

84. Hainfeld, J.F.; Slatkin, D.N.; Smilowitz, H.M. The use of gold nanoparticles to enhance radiotherapy in mice. Phys. Med. Biol. 2004, 49, 309-315. [CrossRef] [PubMed]

85. Her, S.; Jaffray, D.A.; Allen, C. Gold nanoparticles for applications in cancer radiotherapy: Mechanisms and recent advancements. Adv. Drug Deliv. Rev. 2017, 109, 84-101. [CrossRef] [PubMed]

86. Kim, J.K.; Seo, S.J.; Kim, H.T.; Kim, K.H.; Chung, M.H.; Kim, K.R.; Ye, S.J. Enhanced proton treatment in mouse tumors through proton irradiated nanoradiator effects on metallic nanoparticles. Phys. Med. Biol. 2012, 57, 8309-8323. [CrossRef] [PubMed]

87. Shmatov, M.L. Importance of electric fields from ionized nanoparticles for radiation therapy. Phys. Part. Nucl. Lett. 2017, 14, 533-536. [CrossRef]

88. Chen, Q.; Chen, J.; Yang, Z.; Xu, J.; Xu, L.; Liang, C.; Han, X.; Liu, Z. Nanoparticle-Enhanced Radiotherapy to Trigger Robust Cancer Immunotherapy. Adv. Mater. 2019, 31, 1802228. [CrossRef]

89. Chen, J.; Luo, H.; Liu, Y.; Zhang, W.; Li, H.; Luo, T.; Zhang, K.; Zhao, Y.; Liu, J. Oxygen-Self-Produced Nanoplatform for Relieving Hypoxia and Breaking Resistance to Sonodynamic Treatment of Pancreatic Cancer. Acs Nano 2017, 11, 12849-12862. [CrossRef]

90. Bonvalot, S.; Le Pechoux, C.; De Baere, T.; Kantor, G.; Buy, X.; Stoeckle, E.; Terrier, P.; Sargos, P.; Coindre, J.M.; Lassau, N.; et al. First-in-Human Study Testing a New Radioenhancer Using Nanoparticles (NBTXR3) Activated by Radiation Therapy in Patients with Locally Advanced Soft Tissue Sarcomas. Clin. Cancer Res. 2017, 23, 908-917. [CrossRef]

91. Kotb, S.; Detappe, A.; Lux, F.; Appaix, F.; Barbier, E.L.; Tran, V.L.; Plissonneau, M.; Gehan, H.; Lefranc, F.; Rodriguez-Lafrasse, C.; et al. Gadolinium-Based Nanoparticles and Radiation Therapy for Multiple Brain Melanoma Metastases: Proof of Concept before Phase I Trial. Theranostics 2016, 6, 418-427. [CrossRef]

92. Lux, F.; Tran, V.L.; Thomas, E.; Dufort, S.; Rossetti, F.; Martini, M.; Truillet, C.; Doussineau, T.; Bort, G.; Denat, F.; et al. AGuIX®from bench to bedside-Transfer of an ultrasmall theranostic gadolinium-based nanoparticle to clinical medicine. Br. J. Radiol. 2018, 92, 20180365. [CrossRef]

93. Verry, C.; Sancey, L.; Dufort, S.; Le Duc, G.; Mendoza, C.; Lux, F.; Grand, S.; Arnaud, J.; Quesada, J.L.; Villa, J.; et al. Treatment of multiple brain metastases using gadolinium nanoparticles and radiotherapy: NANO-RAD, a phase I study protocol. BMJ Open 2019, 9, 023591. [CrossRef] 
94. Bonvalot, S.; Rutkowski, P.L.; Thariat, J.; Carrère, S.; Ducassou, A.; Sunyach, M.-P.; Agoston, P.; Hong, A.; Mervoyer, A.; Rastrelli, M.; et al. NBTXR3, a first-in-class radioenhancer hafnium oxide nanoparticle, plus radiotherapy versus radiotherapy alone in patients with locally advanced soft-tissue sarcoma (Act.In.Sarc): A multicentre, phase 2-3, randomised, controlled trial. Lancet Oncol. 2019, 20, 1148-1159. [CrossRef]

95. Haymart, M.R.; Banerjee, M.; Stewart, A.K.; Koenig, R.J.; Birkmeyer, J.D.; Griggs, J.J. Use of radioactive iodine for thyroid cancer. JAMA 2011, 306, 721-728. [CrossRef]

96. Vapiwala, N.; Glatstein, E. Fighting Prostate Cancer with Radium-223-Not Your Madame's Isotope. N. Engl. J. Med. 2013, 369, 276-278. [CrossRef] [PubMed]

97. Morschhauser, F.; Radford, J.; Van Hoof, A.; Vitolo, U.; Soubeyran, P.; Tilly, H.; Huijgens, P.C.; Kolstad, A.; d'Amore, F.; Gonzalez Diaz, M.; et al. Phase III trial of consolidation therapy with yttrium-90-ibritumomab tiuxetan compared with no additional therapy after first remission in advanced follicular lymphoma. J. Clin. Oncol. 2008, 26, 5156-5164. [CrossRef]

98. Chargari, C.; Deutsch, E.; Blanchard, P.; Gouy, S.; Martelli, H.; Guerin, F.; Dumas, I.; Bossi, A.; Morice, P.; Viswanathan, A.N.; et al. Brachytherapy: An overview for clinicians. CA Cancer J. Clin. 2019, 69, 386-401. [CrossRef]

99. Pouliot, J.; Beaulieu, L. 13-Modern Principles of Brachytherapy Physics: From 2-D to 3-D to Dynamic Planning and Delivery. In Leibel and Phillips Textbook of Radiation Oncology, 3rd ed.; Hoppe, R.T., Phillips, T.L., Roach, M., Eds.; W.B. Saunders: Philadelphia, PA, USA, 2010; pp. 224-244. [CrossRef]

100. Harrison, L.B.; Shasha, D.; White, C.; Ramdeen, B. Radiotherapy-associated anemia: The scope of the problem. Oncologist 2000, 5, 1-7. [CrossRef]

101. Stacey, R.; Green, J.T. Radiation-induced small bowel disease: Latest developments and clinical guidance. Ther. Adv. Chronic Dis. 2014, 5, 15-29. [CrossRef]

102. Ali, S.Y.; Singh, G. Radiation-induced Alopecia. Int. J. Trichol. 2010, 2, 118-119. [CrossRef]

103. Berrington de Gonzalez, A.; Curtis, R.E.; Kry, S.F.; Gilbert, E.; Lamart, S.; Berg, C.D.; Stovall, M.; Ron, E. Proportion of second cancers attributable to radiotherapy treatment in adults: A cohort study in the US SEER cancer registries. Lancet. Oncol. 2011, 12, 353-360. [CrossRef]

104. Wissing, M.D.; Azoulay, L. Postoperative Pelvic Radiotherapy in Patients With Endometrial Cancer May Increase the Risk for Secondary Pelvic Cancers: A Post Hoc Analysis of Results From the TME, PORTEC-1, and PORTEC-2 Trials. J. Clin. Oncol. 2017, 35, 1861-1862. [CrossRef]

105. Wallis, C.J.; Mahar, A.L.; Choo, R.; Herschorn, S.; Kodama, R.T.; Shah, P.S.; Danjoux, C.; Narod, S.A.; Nam, R.K. Second malignancies after radiotherapy for prostate cancer: Systematic review and meta-analysis. BMJ 2016, 352, i851. [CrossRef] [PubMed]

106. Horwich, A.; Fossa, S.D.; Huddart, R.; Dearnaley, D.P.; Stenning, S.; Aresu, M.; Bliss, J.M.; Hall, E. Second cancer risk and mortality in men treated with radiotherapy for stage I seminoma. Br. J. Cancer 2014, 110, 256-263. [CrossRef] [PubMed]

107. De Sanctis, V.; Alfo, M.; Di Rocco, A.; Ansuinelli, M.; Russo, E.; Osti, M.F.; Valeriani, M.; Minniti, G.; Grapulin, L.; Musio, D.; et al. Second cancer incidence in primary mediastinal B-cell lymphoma treated with methotrexate with leucovorin rescue, doxorubicin, cyclophosphamide, vincristine, prednisone, and bleomycin regimen with or without rituximab and mediastinal radiotherapy: Results from a monoinstitutional cohort analysis of long-term survivors. Hematol. Oncol. 2017, 35, 554-560. [CrossRef] [PubMed]

108. Teng, C.J.; Hu, Y.W.; Chen, S.C.; Yeh, C.M.; Chiang, H.L.; Chen, T.J.; Liu, C.J. Use of Radioactive Iodine for Thyroid Cancer and Risk of Second Primary Malignancy: A Nationwide Population-Based Study. J. Natl. Cancer Inst. 2016, 108. [CrossRef] [PubMed]

109. Molenaar, R.J.; Sidana, S.; Radivoyevitch, T.; Advani, A.S.; Gerds, A.T.; Carraway, H.E.; Angelini, D.; Kalaycio, M.; Nazha, A.; Adelstein, D.J.; et al. Risk of Hematologic Malignancies After Radioiodine Treatment of Well-Differentiated Thyroid Cancer. Surgery 2017, 76, 410. [CrossRef]

110. Morgan, G.; Ward, R.; Barton, M. The contribution of cytotoxic chemotherapy to 5-year survival in adult malignancies. Clin. Oncol. 2004, 16, 549-560. [CrossRef]

111. Lawrie, T.A.; Winter-Roach, B.A.; Heus, P.; Kitchener, H.C. Adjuvant (post-surgery) chemotherapy for early stage epithelial ovarian cancer. Cochrane Database Syst. Rev. 2015, 12. [CrossRef] 
112. Ando, N.; Iizuka, T.; Ide, H.; Ishida, K.; Shinoda, M.; Nishimaki, T.; Takiyama, W.; Watanabe, H.; Isono, K.; Aoyama, N.; et al. Surgery plus chemotherapy compared with surgery alone for localized squamous cell carcinoma of the thoracic esophagus: A Japan Clinical Oncology Group Study-JCOG9204. J. Clin. Oncol. 2003, 21, 4592-4596. [CrossRef]

113. Hu, X.; Li, Y.Q.; Li, Q.G.; Ma, Y.L.; Peng, J.J.; Cai, S.J. Adjuvant Chemotherapy Seemed Not to Have Survival Benefit in Rectal Cancer Patients with ypTis-2N0 After Preoperative Radiotherapy and Surgery from a Population-Based Propensity Score Analysis. Oncologist 2019, 24, 803-811. [CrossRef]

114. Ashdown, M.L.; Robinson, A.P.; Yatomi-Clarke, S.L.; Ashdown, M.L.; Allison, A.; Abbott, D.; Markovic, S.N.; Coventry, B.J. Chemotherapy for Late-Stage Cancer Patients: Meta-Analysis of Complete Response Rates. F1000Research 2015, 4, 232. [CrossRef]

115. Macarulla, T.; Pazo-Cid, R.; Guillén-Ponce, C.; López, R.; Vera, R.; Reboredo, M.; Martin, A.M.; Rivera, F.; Beveridge, R.D.; Casta, A.L.; et al. Phase I/II Trial to Evaluate the Efficacy and Safety of Nanoparticle Albumin-Bound Paclitaxel in Combination With Gemcitabine in Patients With Pancreatic Cancer and an ECOG Performance Status of 2. J. Clin. Oncol. 2019, 37, 230-238. [CrossRef] [PubMed]

116. Cunningham, D.; Starling, N.; Rao, S.; Iveson, T.; Nicolson, M.; Coxon, F.; Middleton, G.; Daniel, F.; Oates, J.; Norman, A.R. Capecitabine and Oxaliplatin for Advanced Esophagogastric Cancer. N. Engl. J. Med. 2008, 358, 36-46. [CrossRef] [PubMed]

117. Fujitani, K.; Yang, H.-K.; Mizusawa, J.; Kim, Y.-W.; Terashima, M.; Han, S.-U.; Iwasaki, Y.; Hyung, W.J.; Takagane, A.; Park, D.J.; et al. Gastrectomy plus chemotherapy versus chemotherapy alone for advanced gastric cancer with a single non-curable factor (REGATTA): A phase 3, randomised controlled trial. Lancet Oncol. 2016, 17, 309-318. [CrossRef]

118. Gandhi, L.; Rodríguez-Abreu, D.; Gadgeel, S.; Esteban, E.; Felip, E.; De Angelis, F.; Domine, M.; Clingan, P.; Hochmair, M.J.; Powell, S.F.; et al. Pembrolizumab plus Chemotherapy in Metastatic Non-Small-Cell Lung Cancer. N. Engl. J. Med. 2018, 378, 2078-2092. [CrossRef] [PubMed]

119. Qin, S.; Bai, Y.; Lim, H.Y.; Thongprasert, S.; Chao, Y.; Fan, J.; Yang, T.S.; Bhudhisawasdi, V.; Kang, W.K.; Zhou, Y.; et al. Randomized, multicenter, open-label study of oxaliplatin plus fluorouracil/leucovorin versus doxorubicin as palliative chemotherapy in patients with advanced hepatocellular carcinoma from Asia. J. Clin. Oncol. 2013, 31, 3501-3508. [CrossRef]

120. Primrose, J.; Falk, S.; Finch-Jones, M.; Valle, J.; O'Reilly, D.; Siriwardena, A.; Hornbuckle, J.; Peterson, M.; Rees, M.; Iveson, T.; et al. Systemic chemotherapy with or without cetuximab in patients with resectable colorectal liver metastasis: The New EPOC randomised controlled trial. Lancet Oncol. 2014, 15, 601-611. [CrossRef]

121. Chera, B.S.; Amdur, R.J.; Green, R.; Shen, C.; Gupta, G.; Tan, X.; Knowles, M.; Fried, D.; Hayes, N.; Weiss, J.; et al. Phase II Trial of De-Intensified Chemoradiotherapy for Human Papillomavirus-Associated Oropharyngeal Squamous Cell Carcinoma. J. Clin. Oncol. 2019, 37, 2661-2669. [CrossRef]

122. Grothey, A.; Sobrero, A.F.; Shields, A.F.; Yoshino, T.; Paul, J.; Taieb, J.; Souglakos, J.; Shi, Q.; Kerr, R.; Labianca, R.; et al. Duration of Adjuvant Chemotherapy for Stage III Colon Cancer. N. Engl. J. Med. 2018, 378, 1177-1188. [CrossRef]

123. Manjelievskaia, J.; Brown, D.; McGlynn, K.A.; Anderson, W.; Shriver, C.D.; Zhu, K. Chemotherapy Use and Survival Among Young and Middle-Aged Patients With Colon Cancer. JAMA Surg. 2017, 152, 452-459. [CrossRef]

124. Guarneri, V.; Dieci, M.V.; Bisagni, G.; Frassoldati, A.; Bianchi, G.V.; De Salvo, G.L.; Orvieto, E.; Urso, L.; Pascual, T.; Pare, L.; et al. De-escalated therapy for HR+/HER2+ breast cancer patients with Ki67 response after 2 weeks letrozole: Results of the PerELISA neoadjuvant study. Ann. Oncol. 2019, 30, 921-926. [CrossRef]

125. Saunders, N.A.; Simpson, F.; Thompson, E.W.; Hill, M.M.; Endo-Munoz, L.; Leggatt, G.; Minchin, R.F.; Guminski, A. Role of intratumoural heterogeneity in cancer drug resistance: Molecular and clinical perspectives. EMBO Mol. Med. 2012, 4, 675-684. [CrossRef]

126. Ramalingam, S.; Belani, C. Systemic chemotherapy for advanced non-small cell lung cancer: Recent advances and future directions. Oncologist 2008, 13, 5-13. [CrossRef] [PubMed]

127. Paik, S. Development and clinical utility of a 21-gene recurrence score prognostic assay in patients with early breast cancer treated with tamoxifen. Oncologist 2007, 12, 631-635. [CrossRef] 
128. Turkington, R.C.; Knight, L.A.; Blayney, J.K.; Secrier, M.; Douglas, R.; Parkes, E.E.; Sutton, E.K.; Stevenson, L.; McManus, D.; Halliday, S.; et al. Immune activation by DNA damage predicts response to chemotherapy and survival in oesophageal adenocarcinoma. Gut 2019. [CrossRef] [PubMed]

129. Sutton, P.; Evans, J.; Jones, R.; Malik, H.; Vimalachandran, D.; Palmer, D.; Goldring, C.; Kitteringham, N. Proteomic analysis to identify biomarkers in the primary tumour that predict response to neoadjuvant chemotherapy in liver metastases. Lancet 2015, 385, 95. [CrossRef]

130. Scagliotti, G.V.; Parikh, P.; von Pawel, J.; Biesma, B.; Vansteenkiste, J.; Manegold, C.; Serwatowski, P.; Gatzemeier, U.; Digumarti, R.; Zukin, M.; et al. Phase III study comparing cisplatin plus gemcitabine with cisplatin plus pemetrexed in chemotherapy-naive patients with advanced-stage non-small-cell lung cancer. J. Clin. Oncol. 2008, 26, 3543-3551. [CrossRef] [PubMed]

131. Zhong, W.Z.; Wang, Q.; Mao, W.M.; Xu, S.T.; Wu, L.; Shen, Y.; Liu, Y.Y.; Chen, C.; Cheng, Y.; Xu, L.; et al. Gefitinib versus vinorelbine plus cisplatin as adjuvant treatment for stage II-IIIA (N1-N2) EGFR-mutant NSCLC (ADJUVANT/CTONG1104): A randomised, open-label, phase 3 study. Lancet Oncol. 2018, 19, 139-148. [CrossRef]

132. Solomon, B.J.; Mok, T.; Kim, D.W.; Wu, Y.L.; Nakagawa, K.; Mekhail, T.; Felip, E.; Cappuzzo, F.; Paolini, J.; Usari, T.; et al. First-line crizotinib versus chemotherapy in ALK-positive lung cancer. N. Engl. J. Med. 2014, 371, 2167-2177. [CrossRef] [PubMed]

133. Mok, T.S.; Wu, Y.L.; Thongprasert, S.; Yang, C.H.; Chu, D.T.; Saijo, N.; Sunpaweravong, P.; Han, B.; Margono, B.; Ichinose, Y.; et al. Gefitinib or carboplatin-Paclitaxel in pulmonary adenocarcinoma. N. Engl. J. Med. 2009, 361, 947-957. [CrossRef]

134. Hellmann, M.D.; Paz-Ares, L.; Bernabe Caro, R.; Zurawski, B.; Kim, S.-W.; Carcereny Costa, E.; Park, K.; Alexandru, A.; Lupinacci, L.; de la Mora Jimenez, E.; et al. Nivolumab plus Ipilimumab in Advanced Non-Small-Cell Lung Cancer. N. Engl. J. Med. 2019. [CrossRef]

135. Wong, J.R.; Morton, L.M.; Tucker, M.A.; Abramson, D.H.; Seddon, J.M.; Sampson, J.N.; Kleinerman, R.A. Risk of subsequent malignant neoplasms in long-term hereditary retinoblastoma survivors after chemotherapy and radiotherapy. J. Clin. Oncol. 2014, 32, 3284-3290. [CrossRef] [PubMed]

136. Nurgali, K.; Jagoe, R.T.; Abalo, R. Editorial: Adverse Effects of Cancer Chemotherapy: Anything New to Improve Tolerance and Reduce Sequelae. Front. Pharmacol. 2018, 9, 245. [CrossRef] [PubMed]

137. Coiffier, B.; Lepage, E.; Brière, J.; Herbrecht, R.; Tilly, H.; Bouabdallah, R.; Morel, P.; Van Den Neste, E.; Salles, G.; Gaulard, P.; et al. CHOP Chemotherapy plus Rituximab Compared with CHOP Alone in Elderly Patients with Diffuse Large-B-Cell Lymphoma. N. Engl. J. Med. 2002, 346, 235-242. [CrossRef] [PubMed]

138. Bergethon, K.; Shaw, A.T.; Ou, S.H.; Katayama, R.; Lovly, C.M.; McDonald, N.T.; Massion, P.P.; Siwak-Tapp, C.; Gonzalez, A.; Fang, R.; et al. ROS1 rearrangements define a unique molecular class of lung cancers. J. Clin. Oncol. 2012, 30, 863-870. [CrossRef]

139. Soda, M.; Choi, Y.L.; Enomoto, M.; Takada, S.; Yamashita, Y.; Ishikawa, S.; Fujiwara, S.; Watanabe, H.; Kurashina, K.; Hatanaka, H.; et al. Identification of the transforming EML4-ALK fusion gene in non-small-cell lung cancer. Nature 2007, 448, 561-566. [CrossRef]

140. Chan, B.A.; Hughes, B.G. Targeted therapy for non-small cell lung cancer: Current standards and the promise of the future. Transl. Lung Cancer Res. 2015, 4, 36-54. [CrossRef]

141. Mok, T.S.; Wu, Y.L.; Ahn, M.J.; Garassino, M.C.; Kim, H.R.; Ramalingam, S.S.; Shepherd, F.A.; He, Y.; Akamatsu, H.; Theelen, W.S.; et al. Osimertinib or Platinum-Pemetrexed in EGFR T790M-Positive Lung Cancer. N. Engl. J. Med. 2017, 376, 629-640. [CrossRef]

142. Carmeliet, P.; Jain, R.K. Angiogenesis in cancer and other diseases. Nature 2000, 407, 249-257. [CrossRef]

143. Qin, S.; Li, A.; Yi, M.; Yu, S.; Zhang, M.; Wu, K. Recent advances on anti-angiogenesis receptor tyrosine kinase inhibitors in cancer therapy. J. Hematol. Oncol. 2019, 12, 27. [CrossRef]

144. Strecker, T.E.; Odutola, S.O.; Lopez, R.; Cooper, M.S.; Tidmore, J.K.; Charlton-Sevcik, A.K.; Li, L.; MacDonough, M.T.; Hadimani, M.B.; Ghatak, A.; et al. The vascular disrupting activity of OXi8006 in endothelial cells and its phosphate prodrug OXi8007 in breast tumor xenografts. Cancer Lett. 2015, 369, 229-241. [CrossRef]

145. Monk, B.J.; Sill, M.W.; Walker, J.L.; Darus, C.J.; Sutton, G.; Tewari, K.S.; Martin, L.P.; Schilder, J.M.; Coleman, R.L.; Balkissoon, J.; et al. Randomized Phase II Evaluation of Bevacizumab Versus Bevacizumab Plus Fosbretabulin in Recurrent Ovarian, Tubal, or Peritoneal Carcinoma: An NRG Oncology/Gynecologic Oncology Group Study. J. Clin. Oncol. 2016, 34, 2279-2286. [CrossRef] [PubMed] 
146. Lara, P.N., Jr.; Douillard, J.Y.; Nakagawa, K.; von Pawel, J.; McKeage, M.J.; Albert, I.; Losonczy, G.; Reck, M.; Heo, D.S.; Fan, X.; et al. Randomized phase III placebo-controlled trial of carboplatin and paclitaxel with or without the vascular disrupting agent vadimezan (ASA404) in advanced non-small-cell lung cancer. J. Clin. Oncol. 2011, 29, 2965-2971. [CrossRef] [PubMed]

147. Rudin, C.M.; Mauer, A.; Smakal, M.; Juergens, R.; Spelda, S.; Wertheim, M.; Coates, A.; McKeegan, E.; Ansell, P.; Zhou, X.; et al. Phase I/II study of pemetrexed with or without ABT-751 in advanced or metastatic non-small-cell lung cancer. J. Clin. Oncol. 2011, 29, 1075-1082. [CrossRef]

148. Hodi, F.S.; O’Day, S.J.; McDermott, D.F.; Weber, R.W.; Sosman, J.A.; Haanen, J.B.; Gonzalez, R.; Robert, C.; Schadendorf, D.; Hassel, J.C.; et al. Improved survival with ipilimumab in patients with metastatic melanoma. N. Engl. J. Med. 2010, 363, 711-723. [CrossRef] [PubMed]

149. Robert, C.; Thomas, L.; Bondarenko, I.; O’Day, S.; Weber, J.; Garbe, C.; Lebbe, C.; Baurain, J.-F.; Testori, A.; Grob, J.-J.; et al. Ipilimumab plus Dacarbazine for Previously Untreated Metastatic Melanoma. N. Engl. J. Med. 2011, 364, 2517-2526. [CrossRef]

150. Schadendorf, D.; Hodi, F.S.; Robert, C.; Weber, J.S.; Margolin, K.; Hamid, O.; Patt, D.; Chen, T.T.; Berman, D.M.; Wolchok, J.D. Pooled Analysis of Long-Term Survival Data From Phase II and Phase III Trials of Ipilimumab in Unresectable or Metastatic Melanoma. J. Clin. Oncol. 2015, 33, 1889-1894. [CrossRef] [PubMed]

151. Eroglu, Z.; Kim, D.W.; Wang, X.; Camacho, L.H.; Chmielowski, B.; Seja, E.; Villanueva, A.; Ruchalski, K.; Glaspy, J.A.; Kim, K.B.; et al. Long term survival with cytotoxic T lymphocyte-associated antigen 4 blockade using tremelimumab. Eur. J. Cancer 2015, 51, 2689-2697. [CrossRef]

152. Robert, C.; Ribas, A.; Hamid, O.; Daud, A.; Wolchok, J.D.; Joshua, A.M.; Hwu, W.J.; Weber, J.S.; Gangadhar, T.C.; Joseph, R.W.; et al. Durable Complete Response After Discontinuation of Pembrolizumab in Patients With Metastatic Melanoma. J. Clin. Oncol. 2018, 36, 1668-1674. [CrossRef]

153. Gong, J.; Chehrazi-Raffle, A.; Reddi, S.; Salgia, R. Development of PD-1 and PD-L1 inhibitors as a form of cancer immunotherapy: A comprehensive review of registration trials and future considerations. J. Immunother. Cancer 2018, 6, 8. [CrossRef]

154. Le, D.T.; Durham, J.N.; Smith, K.N.; Wang, H.; Bartlett, B.R.; Aulakh, L.K.; Lu, S.; Kemberling, H.; Wilt, C.; Luber, B.S.; et al. Mismatch repair deficiency predicts response of solid tumors to PD-1 blockade. Science 2017, 357, 409-413. [CrossRef]

155. Larkin, J.; Chiarion-Sileni, V.; Gonzalez, R.; Grob, J.-J.; Rutkowski, P.; Lao, C.D.; Cowey, C.L.; Schadendorf, D.; Wagstaff, J.; Dummer, R.; et al. Five-Year Survival with Combined Nivolumab and Ipilimumab in Advanced Melanoma. N. Engl. J. Med. 2019, 381, 1535-1546. [CrossRef] [PubMed]

156. Andrews, A. Treating with Checkpoint Inhibitors-Figure $\$ 1$ Million per Patient. Am. Health Drug Benefits 2015, 8, 9. [PubMed]

157. Bianco, A.; Perrotta, F.; Barra, G.; Malapelle, U.; Rocco, D.; De Palma, R. Prognostic Factors and Biomarkers of Responses to Immune Checkpoint Inhibitors in Lung Cancer. Int. J. Mol. Sci. 2019, 20, 4931. [CrossRef] [PubMed]

158. Havel, J.J.; Chowell, D.; Chan, T.A. The evolving landscape of biomarkers for checkpoint inhibitor immunotherapy. Nat. Rev. Cancer 2019, 19, 133-150. [CrossRef]

159. Pinato, D.J.; Howlett, S.; Ottaviani, D.; Urus, H.; Patel, A.; Mineo, T.; Brock, C.; Power, D.; Hatcher, O.; Falconer, A.; et al. Association of Prior Antibiotic Treatment With Survival and Response to Immune Checkpoint Inhibitor Therapy in Patients With Cancer. JAMA Oncol. 2019. [CrossRef]

160. Champiat, S.; Dercle, L.; Ammari, S.; Massard, C.; Hollebecque, A.; Postel-Vinay, S.; Chaput, N.; Eggermont, A.; Marabelle, A.; Soria, J.C.; et al. Hyperprogressive Disease Is a New Pattern of Progression in Cancer Patients Treated by Anti-PD-1/PD-L1. Clin. Cancer Res. 2017, 23, 1920-1928. [CrossRef]

161. Wang, D.Y.; Salem, J.E.; Cohen, J.V.; Chandra, S.; Menzer, C.; Ye, F.; Zhao, S.; Das, S.; Beckermann, K.E.; Ha, L.; et al. Fatal Toxic Effects Associated With Immune Checkpoint Inhibitors: A Systematic Review and Meta-analysis. JAMA Oncol. 2018, 4, 1721-1728. [CrossRef]

162. Albano, D.; Bilfinger, T.; Nemesure, B. 1-, 3-, and 5-year survival among early-stage lung cancer patients treated with lobectomy vs SBRT. Lung Cancer 2018, 9, 65-71. [CrossRef]

163. Ma, K.W.; Cheung, T.T. Surgical resection of localized hepatocellular carcinoma: Patient selection and special consideration. J. Hepatocell. Carcinoma 2017, 4, 1-9. [CrossRef] 
164. Takagi, T.; Kondo, T.; Iizuka, J.; Omae, K.; Kobayashi, H.; Yoshida, K.; Hashimoto, Y.; Tanabe, K. Comparison of survival rates in stage 1 renal cell carcinoma between partial nephrectomy and radical nephrectomy patients according to age distribution: A propensity score matching study. BJU Int. 2016, 117, 52-59. [CrossRef]

165. Maca, J.; Peteja, M.; Reimer, P.; Jor, O.; Sedenkova, V.; Panackova, L.; Ihnat, P.; Burda, M.; Sevcik, P. Surgical injury: Comparing open surgery and laparoscopy by markers of tissue damage. Ther. Clin. Risk Manag. 2018, 14, 999-1006. [CrossRef] [PubMed]

166. Tohme, S.; Simmons, R.L.; Tsung, A. Surgery for Cancer: A Trigger for Metastases. Cancer Res. 2017, 77, 1548-1552. [CrossRef] [PubMed]

167. Lai, E.C.; Yang, G.P.; Tang, C.N. Robot-assisted laparoscopic liver resection for hepatocellular carcinoma: Short-term outcome. Am. J. Surg. 2013, 205, 697-702. [CrossRef]

168. Coughlin, G.D.; Yaxley, J.W.; Chambers, S.K.; Occhipinti, S.; Samaratunga, H.; Zajdlewicz, L.; Teloken, P.; Dunglison, N.; Williams, S.; Lavin, M.F.; et al. Robot-assisted laparoscopic prostatectomy versus open radical retropubic prostatectomy: 24-month outcomes from a randomised controlled study. Lancet Oncol. 2018, 19, 1051-1060. [CrossRef]

169. Uedo, N.; Takeuchi, Y.; Ishihara, R. Endoscopic management of early gastric cancer: Endoscopic mucosal resection or endoscopic submucosal dissection: Data from a Japanese high-volume center and literature review. Ann. Gastroenterol. 2012, 25, 281-290.

170. Ribeiro, M.S.; Wallace, M.B. Endoscopic Treatment of Early Cancer of the Colon. Gastroenterol. Hepatol. 2015, 11, 445-452.

171. Backes, Y.; de Vos Tot Nederveen Cappel, W.H.; van Bergeijk, J.; Ter Borg, F.; Schwartz, M.P.; Spanier, B.W.M.; Geesing, J.M.J.; Kessels, K.; Kerkhof, M.; Groen, J.N.; et al. Risk for Incomplete Resection after Macroscopic Radical Endoscopic Resection of T1 Colorectal Cancer: A Multicenter Cohort Study. Am. J. Gastroenterol. 2017, 112, 785-796. [CrossRef]

172. Anderson, M.L.; Pasha, T.M.; Leighton, J.A. Endoscopic perforation of the colon: Lessons from a 10-year study. Am. J. Gastroenterol. 2000, 95, 3418-3422. [CrossRef]

173. Chen, M.S.; Li, J.Q.; Zheng, Y.; Guo, R.P.; Liang, H.H.; Zhang, Y.Q.; Lin, X.J.; Lau, W.Y. A prospective randomized trial comparing percutaneous local ablative therapy and partial hepatectomy for small hepatocellular carcinoma. Ann. Surg. 2006, 243, 321-328. [CrossRef]

174. Talenfeld, A.D.; Gennarelli, R.L.; Elkin, E.B.; Atoria, C.L.; Durack, J.C.; Huang, W.C.; Kwan, S.W. Percutaneous Ablation Versus Partial and Radical Nephrectomy for T1a Renal Cancer: A Population-Based Analysis. Ann. Intern. Med. 2018, 169, 69-77. [CrossRef]

175. Kim, S.R.; Han, H.J.; Park, S.J.; Min, K.H.; Lee, M.H.; Chung, C.R.; Kim, M.H.; Jin, G.Y.; Lee, Y.C. Comparison between surgery and radiofrequency ablation for stage I non-small cell lung cancer. Eur.J. Radiol. 2012, 81, 395-399. [CrossRef] [PubMed]

176. Yoon, G.S.; Wang, W.; Osunkoya, A.O.; Lane, Z.; Partin, A.W.; Epstein, J.I. Residual tumor potentially left behind after local ablation therapy in prostate adenocarcinoma. J. Urol. 2008, 179, 2203-2206. [CrossRef] [PubMed]

177. Zhou, C.; Wei, B.; Gao, K.; Zhai, R. Biliary tract perforation following percutaneous endobiliary radiofrequency ablation: A report of two cases. Oncol. Lett. 2016, 11, 3813-3816. [CrossRef]

178. Fonseca, A.Z.; Santin, S.; Gomes, L.G.; Waisberg, J.; Ribeiro, M.A., Jr. Complications of radiofrequency ablation of hepatic tumors: Frequency and risk factors. World J. Hepatol. 2014, 6, 107-113. [CrossRef]

179. Lencioni, R.; Petruzzi, P.; Crocetti, L. Chemoembolization of hepatocellular carcinoma. Semin. Interv. Radiol. 2013, 30, 3-11. [CrossRef]

180. Seam, P.; Janik, J.E.; Longo, D.L.; Devita, V.T., Jr. Role of chemotherapy in Hodgkin's lymphoma. Cancer J. 2009, 15, 150-154. [CrossRef]

181. Terwilliger, T.; Abdul-Hay, M. Acute lymphoblastic leukemia: A comprehensive review and 2017 update. Blood Cancer J. 2017, 7, e577. [CrossRef]

182. Alexander, E.J.; White, I.M.; Horwich, A. Update on management of seminoma. Indian J. Urol. 2010, 26, 82-91. [CrossRef]

183. Boffetta, P.; Kaldor, J.M. Secondary malignancies following cancer chemotherapy. Acta Oncol. 1994, 33, 591-598. [CrossRef]

184. Menon, S.P.; Rajkumar, S.V.; Lacy, M.; Falco, P.; Palumbo, A. Thromboembolic events with lenalidomide-based therapy for multiple myeloma. Cancer 2008, 112, 1522-1528. [CrossRef] 
185. Vincent, L.; Kermani, P.; Young, L.M.; Cheng, J.; Zhang, F.; Shido, K.; Lam, G.; Bompais-Vincent, H.; Zhu, Z.; Hicklin, D.J.; et al. Combretastatin A4 phosphate induces rapid regression of tumor neovessels and growth through interference with vascular endothelial-cadherin signaling. J. Clin. Investig. 2005, 115, 2992-3006. [CrossRef] [PubMed]

186. Zimmermann, M.; Oehler, C.; Mey, U.; Ghadjar, P.; Zwahlen, D.R. Radiotherapy for Non-Hodgkin's lymphoma: Still standard practice and not an outdated treatment option. Radiat. Oncol. 2016, 11, 110. [CrossRef] [PubMed]

187. Chen, Y.P.; Chan, A.T.C.; Le, Q.T.; Blanchard, P.; Sun, Y.; Ma, J. Nasopharyngeal carcinoma. Lancet 2019, 394, 64-80. [CrossRef]

188. Newhauser, W.D.; Berrington de Gonzalez, A.; Schulte, R.; Lee, C. A Review of Radiotherapy-Induced Late Effects Research after Advanced Technology Treatments. Front. Oncol. 2016, 6, 13. [CrossRef]

189. Mohamad, O.; Tabuchi, T.; Nitta, Y.; Nomoto, A.; Sato, A.; Kasuya, G.; Makishima, H.; Choy, H.; Yamada, S.; Morishima, T.; et al. Risk of subsequent primary cancers after carbon ion radiotherapy, photon radiotherapy, or surgery for localised prostate cancer: A propensity score-weighted, retrospective, cohort study. Lancet Oncol. 2019, 20, 674-685. [CrossRef]

190. Florenzano, P.; Guarda, F.J.; Jaimovich, R.; Droppelmann, N.; González, H.; Domínguez, J.M. Radioactive Iodine Administration Is Associated with Persistent Related Symptoms in Patients with Differentiated Thyroid Cancer. Int. J. Endocrinol. 2016, 2016, 2586512. [CrossRef]

191. Teunissen, J.J.; Kwekkeboom, D.J.; Krenning, E.P. Quality of life in patients with gastroenteropancreatic tumors treated with [177Lu-DOTA0,Tyr3]octreotate. J. Clin. Oncol. 2004, 22, 2724-2729. [CrossRef]

192. Brabander, T.; van der Zwan, W.A.; Teunissen, J.J.M.; Kam, B.L.R.; Feelders, R.A.; de Herder, W.W.; van Eijck, C.H.J.; Franssen, G.J.H.; Krenning, E.P.; Kwekkeboom, D.J. Long-Term Efficacy, Survival, and Safety of [(177)Lu-DOTA(0),Tyr(3)]octreotate in Patients with Gastroenteropancreatic and Bronchial Neuroendocrine Tumors. Clin. Cancer Res. 2017, 23, 4617-4624. [CrossRef]

193. Logghe, P.; Verlinde, R.; Bouttens, F.; Van den Broecke, C.; Deman, N.; Verboven, K.; Maes, D.; Merckx, L. Long term outcome and side effects in patients receiving low-dose I125 brachytherapy: A retrospective analysis. Int. Braz. J. Urol. 2016, 42, 906-917. [CrossRef]

194. Lönn, S.; Gilbert, E.S.; Ron, E.; Smith, S.A.; Stovall, M.; Curtis, R.E. Comparison of second cancer risks from brachytherapy and external beam therapy after uterine corpus cancer. Cancer Epidemiol. Biomark. Prev. 2010, 19, 464-474. [CrossRef]

195. Groenendijk, F.H.; Bernards, R. Drug resistance to targeted therapies: Deja vu all over again. Mol. Oncol. 2014, 8, 1067-1083. [CrossRef] [PubMed]

196. Shih, Y.C.; Smieliauskas, F.; Geynisman, D.M.; Kelly, R.J.; Smith, T.J. Trends in the Cost and Use of Targeted Cancer Therapies for the Privately Insured Nonelderly: 2001 to 2011. J. Clin. Oncol. 2015, 33, 2190-2196. [CrossRef] [PubMed]

197. Zarrin, B.; Zarifi, F.; Vaseghi, G.; Javanmard, S.H. Acquired tumor resistance to antiangiogenic therapy: Mechanisms at a glance. J. Res. Med. Sci. 2017, 22, 117. [CrossRef]

198. Venook, A.P.; Niedzwiecki, D.; Lenz, H.J.; Innocenti, F.; Fruth, B.; Meyerhardt, J.A.; Schrag, D.; Greene, C.; O'Neil, B.H.; Atkins, J.N.; et al. Effect of First-Line Chemotherapy Combined With Cetuximab or Bevacizumab on Overall Survival in Patients With KRAS Wild-Type Advanced or Metastatic Colorectal Cancer: A Randomized Clinical Trial. JAMA 2017, 317, 2392-2401. [CrossRef]

199. Choi, Y.I.; Lee, S.H.; Ahn, B.K.; Baek, S.U.; Park, S.J.; Kim, Y.S.; Shin, S.H. Intestinal perforation in colorectal cancers treated with bevacizumab (Avastin). Cancer Res. Treat. 2008, 40, 33-35. [CrossRef]

200. Johnson, D.H.; Fehrenbacher, L.; Novotny, W.F.; Herbst, R.S.; Nemunaitis, J.J.; Jablons, D.M.; Langer, C.J.; DeVore, R.F., 3rd; Gaudreault, J.; Damico, L.A.; et al. Randomized phase II trial comparing bevacizumab plus carboplatin and paclitaxel with carboplatin and paclitaxel alone in previously untreated locally advanced or metastatic non-small-cell lung cancer. J. Clin. Oncol. 2004, 22, 2184-2191. [CrossRef]

201. Haslam, A.; Prasad, V. Estimation of the Percentage of US Patients With Cancer Who Are Eligible for and Respond to Checkpoint Inhibitor Immunotherapy Drugs. JAMA Netw. Open 2019, 2, 192535. [CrossRef]

202. Hartmann, J.; Schüßler-Lenz, M.; Bondanza, A.; Buchholz, C.J. Clinical development of CAR T cells-challenges and opportunities in translating innovative treatment concepts. EMBO Mol. Med. 2017, 9, 1183-1197. [CrossRef] 
203. Hay, A.E.; Cheung, M.C. CAR T-cells: Costs, comparisons, and commentary. J. Med. Econ. 2019, $22,613-615$. [CrossRef]

204. Santomasso, B.; Bachier, C.; Westin, J.; Rezvani, K.; Shpall, E.J. The Other Side of CAR T-Cell Therapy: Cytokine Release Syndrome, Neurologic Toxicity, and Financial Burden. Am. Soc. Clin. Oncol. Educ. Book 2019, 39, 433-444. [CrossRef]

205. Martin, P.J.; Counts, G.W., Jr.; Appelbaum, F.R.; Lee, S.J.; Sanders, J.E.; Deeg, H.J.; Flowers, M.E.; Syrjala, K.L.; Hansen, J.A.; Storb, R.F.; et al. Life expectancy in patients surviving more than 5 years after hematopoietic cell transplantation. J. Clin. Oncol. 2010, 28, 1011-1016. [CrossRef] [PubMed]

206. Biggs, J.C.; Horowitz, M.M.; Gale, R.P.; Ash, R.C.; Atkinson, K.; Helbig, W.; Jacobsen, N.; Phillips, G.L.; Rimm, A.A.; Ringden, O.; et al. Bone marrow transplants may cure patients with acute leukemia never achieving remission with chemotherapy. Blood 1992, 80, 1090-1093. [CrossRef] [PubMed]

207. Brown, J.R.; Feng, Y.; Gribben, J.G.; Neuberg, D.; Fisher, D.C.; Mauch, P.; Nadler, L.M.; Freedman, A.S. Long-term survival after autologous bone marrow transplantation for follicular lymphoma in first remission. Biol. Blood Marrow Transplant. 2007, 13, 1057-1065. [CrossRef] [PubMed]

208. Mateos, M.K.; O’Brien, T.A.; Oswald, C.; Gabriel, M.; Ziegler, D.S.; Cohn, R.J.; Russell, S.J.; Barbaric, D.; Marshall, G.M.; Trahair, T.N. Transplant-related mortality following allogeneic hematopoeitic stem cell transplantation for pediatric acute lymphoblastic leukemia: 25-year retrospective review. Pediatr. Blood Cancer 2013, 60, 1520-1527. [CrossRef] [PubMed]

209. de Heredia, C.D.; Moreno, A.; Olive, T.; Iglesias, J.; Ortega, J.J. Role of the intensive care unit in children undergoing bone marrow transplantation with life-threatening complications. Bone Marrow Transplant. 1999, 24, 163-168. [CrossRef] [PubMed]

210. Litwin, M.S.; Tan, H.J. The Diagnosis and Treatment of Prostate Cancer: A Review. JAMA 2017, 317, 2532-2542. [CrossRef]

211. Waks, A.G.; Winer, E.P. Breast Cancer Treatment: A Review. JAMA 2019, 321, 288-300. [CrossRef]

212. Marcheselli, R.; Marcheselli, L.; Cortesi, L.; Bari, A.; Cirilli, C.; Pozzi, S.; Ferri, P.; Napolitano, M.; Federico, M.; Sacchi, S. Risk of Second Primary Malignancy in Breast Cancer Survivors: A Nested Population-Based Case-Control Study. J. Breast Cancer 2015, 18, 378-385. [CrossRef]

213. Surveillance, Epidemiology, and End Results (SEER) Program SEER Stat Database: Incidence-SEER 9 Regs Research Data, Nov 2018 Sub (1975-2016) (Katrina/Rita Population Adjustment) -Linked To County Attributes-Total U.S., 1969-2017 Counties, National Cancer Institute, DCCPS, Surveillance Research Program. Available online: www.seer.cancer.gov (accessed on 7 November 2019).

214. Schiffman, J.D.; Fisher, P.G.; Gibbs, P. Early detection of cancer: Past, present, and future. Am. Soc. Clin. Oncol. Educ. Book. 2015, 35, 57-65. [CrossRef]

215. Apolone, G.; Joppi, R.; Bertele, V.; Garattini, S. Ten years of marketing approvals of anticancer drugs in Europe: Regulatory policy and guidance documents need to find a balance between different pressures. Br. J. Cancer 2005, 93, 504-509. [CrossRef]

216. Fojo, T.; Mailankody, S.; Lo, A. Unintended consequences of expensive cancer therapeutics-the pursuit of marginal indications and a me-too mentality that stifles innovation and creativity: The John Conley Lecture. JAMA Otolaryngol. Head Neck Surg. 2014, 140, 1225-1236. [CrossRef] [PubMed]

217. Hiom, S.C. Diagnosing cancer earlier: Reviewing the evidence for improving cancer survival. Br. J. Cancer 2015, 112, 1-5. [CrossRef] [PubMed]

218. Wise, P.H. Cancer drugs, survival, and ethics. BMJ 2016, 355, 5792. [CrossRef]

219. Goldsmith, S.J. Radioactive Iodine Therapy of Differentiated Thyroid Carcinoma: Redesigning the Paradigm. Mol Imaging Radionucl Ther 2017, 26, 74-79. [CrossRef]

220. Naci, H.; Davis, C.; Savović, J.; Higgins, J.P.T.; Sterne, J.A.C.; Gyawali, B.; Romo-Sandoval, X.; Handley, N.; Booth, C.M. Design characteristics, risk of bias, and reporting of randomised controlled trials supporting approvals of cancer drugs by European Medicines Agency, 2014-2016: Cross sectional analysis. BMJ 2019, 366, 15221. [CrossRef]

221. Cramer, J.D.; Burtness, B.; Le, Q.T.; Ferris, R.L. The changing therapeutic landscape of head and neck cancer. Nat. Rev. Clin. Oncol. 2019, 16, 669-683. [CrossRef]

222. Cabanillas, M.E.; McFadden, D.G.; Durante, C. Thyroid cancer. Lancet 2016, 388, 2783-2795. [CrossRef]

223. Hirsch, F.R.; Scagliotti, G.V.; Mulshine, J.L.; Kwon, R.; Curran, W.J., Jr.; Wu, Y.L.; Paz-Ares, L. Lung cancer: Current therapies and new targeted treatments. Lancet 2017, 389, 299-311. [CrossRef] 
224. Spencer, K.L.; Kennedy, M.P.T.; Lummis, K.L.; Ellames, D.A.B.; Snee, M.; Brunelli, A.; Franks, K.; Callister, M.E.J. Surgery or radiotherapy for stage I lung cancer? An intention-to-treat analysis. Eur. Respir. J. 2019, 53, 1801568. [CrossRef]

225. Gazdar, A.F.; Bunn, P.A.; Minna, J.D. Small-cell lung cancer: What we know, what we need to know and the path forward. Nat. Rev. Cancer 2017, 17, 725-737. [CrossRef]

226. Lagergren, J.; Smyth, E.; Cunningham, D.; Lagergren, P. Oesophageal cancer. Lancet 2017, 390, $2383-2396$. [CrossRef]

227. Kojima, T.; Muro, K.; Francois, E.; Hsu, C.-H.; Moriwaki, T.; Kim, S.-B.; Lee, S.-H.; Bennouna, J.; Kato, K.; Lin, S.; et al. Pembrolizumab versus chemotherapy as second-line therapy for advanced esophageal cancer: Phase III KEYNOTE-181 study. J. Clin. Oncol. 2019, 37, 2. [CrossRef]

228. Villanueva, A. Hepatocellular Carcinoma. N. Engl. J. Med. 2019, 380, 1450-1462. [CrossRef] [PubMed]

229. Kamisawa, T.; Wood, L.D.; Itoi, T.; Takaori, K. Pancreatic cancer. Lancet 2016, 388, 73-85. [CrossRef]

230. Brenner, H.; Kloor, M.; Pox, C.P. Colorectal cancer. Lancet 2014, 383, 1490-1502. [CrossRef]

231. Shridhar, R.; Shibata, D.; Chan, E.; Thomas, C.R. Anal cancer: Current standards in care and recent changes in practice. CA Cancer J. Clin. 2015, 65, 139-162. [CrossRef]

232. Capitanio, U.; Montorsi, F. Renal cancer. Lancet 2016, 387, 894-906. [CrossRef]

233. Kamat, A.M.; Hahn, N.M.; Efstathiou, J.A.; Lerner, S.P.; Malmstrom, P.U.; Choi, W.; Guo, C.C.; Lotan, Y.; Kassouf, W. Bladder cancer. Lancet 2016, 388, 2796-2810. [CrossRef]

234. Hanna, N.H.; Einhorn, L.H. Testicular cancer-discoveries and updates. N. Engl. J. Med. 2014, 371, $2005-2016$. [CrossRef]

235. Jayson, G.C.; Kohn, E.C.; Kitchener, H.C.; Ledermann, J.A. Ovarian cancer. Lancet 2014, 384, $1376-1388$. [CrossRef]

236. Morice, P.; Leary, A.; Creutzberg, C.; Abu-Rustum, N.; Darai, E. Endometrial cancer. Lancet 2016, 387, 1094-1108. [CrossRef]

237. Cohen, P.A.; Jhingran, A.; Oaknin, A.; Denny, L. Cervical cancer. Lancet 2019, 393, 169-182. [CrossRef]

238. Schadendorf, D.; van Akkooi, A.C.J.; Berking, C.; Griewank, K.G.; Gutzmer, R.; Hauschild, A.; Stang, A.; Roesch, A.; Ugurel, S. Melanoma. Lancet 2018, 392, 971-984. [CrossRef]

239. Hunger, S.P.; Mullighan, C.G. Acute Lymphoblastic Leukemia in Children. N. Engl. J. Med. 2015, 373, 1541-1552. [CrossRef]

240. Hucks, G.; Rheingold, S.R. The journey to CAR T cell therapy: The pediatric and young adult experience with relapsed or refractory B-ALL. Blood Cancer J. 2019, 9, 1-9. [CrossRef]

241. Dohner, H.; Weisdorf, D.J.; Bloomfield, C.D. Acute Myeloid Leukemia. N. Engl. J. Med. 2015, 373, 1136-1152. [CrossRef]

242. Hofmann, S.; Schubert, M.L.; Wang, L.; He, B.; Neuber, B.; Dreger, P.; Muller-Tidow, C.; Schmitt, M. Chimeric Antigen Receptor (CAR) T Cell Therapy in Acute Myeloid Leukemia (AML). J. Clin. Med. 2019, 8, 200. [CrossRef]

243. Nabhan, C.; Rosen, S.T. Chronic lymphocytic leukemia: A clinical review. JAMA 2014, 312, $2265-2276$. [CrossRef]

244. Apperley, J.F. Chronic myeloid leukaemia. Lancet 2015, 385, 1447-1459. [CrossRef]

245. Otto, S.J.; Fracheboud, J.; Looman, C.W.N.; Broeders, M.J.M.; Boer, R.; Hendriks, J.H.C.L.; Verbeek, A.L.M.; de Koning, H.J. Initiation of population-based mammography screening in Dutch municipalities and effect on breast-cancer mortality: A systematic review. Lancet 2003, 361, 1411-1417. [CrossRef]

246. Davies, L.; Welch, H.G. Current thyroid cancer trends in the United States. JAMA Otolaryngol. Head Neck Surg. 2014, 140, 317-322. [CrossRef] [PubMed]

247. Schoen, R.E.; Pinsky, P.F.; Weissfeld, J.L.; Yokochi, L.A.; Church, T.; Laiyemo, A.O.; Bresalier, R.; Andriole, G.L.; Buys, S.S.; Crawford, E.D.; et al. Colorectal-cancer incidence and mortality with screening flexible sigmoidoscopy. N. Engl. J. Med. 2012, 366, 2345-2357. [CrossRef] [PubMed]

248. Landy, R.; Pesola, F.; Castanon, A.; Sasieni, P. Impact of cervical screening on cervical cancer mortality: Estimation using stage-specific results from a nested case-control study. Br. J. Cancer 2016, 115, 1140-1146. [CrossRef] [PubMed]

249. Atkin, W.S.; Edwards, R.; Kralj-Hans, I.; Wooldrage, K.; Hart, A.R.; Northover, J.M.; Parkin, D.M.; Wardle, J.; Duffy, S.W.; Cuzick, J.; et al. Once-only flexible sigmoidoscopy screening in prevention of colorectal cancer: A multicentre randomised controlled trial. Lancet 2010, 375, 1624-1633. [CrossRef] 
250. Welch, H.G.; Woloshin, S.; Schwartz, L.M. Skin biopsy rates and incidence of melanoma: Population based ecological study. BMJ 2005, 331, 481. [CrossRef]

251. Welch, H.G.; Prorok, P.C.; O’Malley, A.J.; Kramer, B.S. Breast-Cancer Tumor Size, Overdiagnosis, and Mammography Screening Effectiveness. N. Engl. J. Med. 2016, 375, 1438-1447. [CrossRef]

252. Bleyer, A.; Welch, H.G. Effect of three decades of screening mammography on breast-cancer incidence. N. Engl. J. Med. 2012, 367, 1998-2005. [CrossRef]

253. Lowenstein, L.M.; Basourakos, S.P.; Williams, M.D.; Troncoso, P.; Gregg, J.R.; Thompson, T.C.; Kim, J. Active surveillance for prostate and thyroid cancers: Evolution in clinical paradigms and lessons learned. Nat. Rev. Clin. Oncol. 2019, 16, 168-184. [CrossRef]

254. Siu, A.L. Screening for Breast Cancer: U.S. Preventive Services Task Force Recommendation Statement. Ann. Intern. Med. 2016, 164, 279-296. [CrossRef]

255. Welch, H.G.; Black, W.C. Overdiagnosis in cancer. J. Natl. Cancer Inst. 2010, 102, 605-613. [CrossRef]

256. Bach, P.B. Reduced lung-cancer mortality with CT screening. N. Engl. J. Med. 2011, 365, 2035-2037. [CrossRef]

257. Otto, S.J.; Fracheboud, J.; Verbeek, A.L.; Boer, R.; Reijerink-Verheij, J.C.; Otten, J.D.; Broeders, M.J.; de Koning, H.J. Mammography screening and risk of breast cancer death: A population-based case-control study. Cancer Epidemiol. Biomark. Prev. 2012, 21, 66-73. [CrossRef]

258. Nelson, H.D.; Tyne, K.; Naik, A.; Bougatsos, C.; Chan, B.K.; Humphrey, L. Screening for breast cancer: An update for the U.S. Preventive Services Task Force. Ann. Intern. Med. 2009, 151, 727-737. [CrossRef] [PubMed]

259. Porter, P.L.; El-Bastawissi, A.Y.; Mandelson, M.T.; Lin, M.G.; Khalid, N.; Watney, E.A.; Cousens, L.; White, D.; Taplin, S.; White, E. Breast tumor characteristics as predictors of mammographic detection: Comparison of interval- and screen-detected cancers. J. Natl. Cancer Inst. 1999, 91, 2020-2028. [CrossRef]

260. Grossman, D.C.; Curry, S.J.; Owens, D.K.; Bibbins-Domingo, K.; Caughey, A.B.; Davidson, K.W.; Doubeni, C.A.; Ebell, M.; Epling, J.W., Jr.; Kemper, A.R.; et al. Screening for Prostate Cancer: US Preventive Services Task Force Recommendation Statement. JAMA 2018, 319, 1901-1913. [CrossRef]

261. Thompson, I.M.; Pauler, D.K.; Goodman, P.J.; Tangen, C.M.; Lucia, M.S.; Parnes, H.L.; Minasian, L.M.; Ford, L.G.; Lippman, S.M.; Crawford, E.D.; et al. Prevalence of prostate cancer among men with a prostate-specific antigen level <or $=4.0 \mathrm{ng}$ per milliliter. N. Engl. J. Med. 2004, 350, 2239-2246. [CrossRef]

262. Etzioni, R.; Penson, D.F.; Legler, J.M.; di Tommaso, D.; Boer, R.; Gann, P.H.; Feuer, E.J. Overdiagnosis due to prostate-specific antigen screening: Lessons from U.S. prostate cancer incidence trends. J. Natl. Cancer Inst. 2002, 94, 981-990. [CrossRef]

263. Carter, H.B.; Piantadosi, S.; Isaacs, J.T. Clinical evidence for and implications of the multistep development of prostate cancer. J. Urol. 1990, 143, 742-746. [CrossRef]

264. Etzioni, R.; Cha, R.; Feuer, E.J.; Davidov, O. Asymptomatic incidence and duration of prostate cancer. Am. J. Epidemiol. 1998, 148, 775-785. [CrossRef]

265. Pickhardt, P.J.; Kim, D.H.; Pooler, B.D.; Hinshaw, J.L.; Barlow, D.; Jensen, D.; Reichelderfer, M.; Cash, B.D. Assessment of volumetric growth rates of small colorectal polyps with CT colonography: A longitudinal study of natural history. Lancet. Oncol. 2013, 14, 711-720. [CrossRef]

266. Knudsen, A.B.; Zauber, A.G.; Rutter, C.M.; Naber, S.K.; Doria-Rose, V.P.; Pabiniak, C.; Johanson, C.; Fischer, S.E.; Lansdorp-Vogelaar, I.; Kuntz, K.M. Estimation of Benefits, Burden, and Harms of Colorectal Cancer Screening Strategies: Modeling Study for the US Preventive Services Task Force. JAMA 2016, 315, 2595-2609. [CrossRef] [PubMed]

267. Bretthauer, M.; Kaminski, M.F.; Loberg, M.; Zauber, A.G.; Regula, J.; Kuipers, E.J.; Hernan, M.A.; McFadden, E.; Sunde, A.; Kalager, M.; et al. Population-Based Colonoscopy Screening for Colorectal Cancer: A Randomized Clinical Trial. JAMA Intern. Med. 2016, 176, 894-902. [CrossRef] [PubMed]

268. Xu, R.H.; Wei, W.; Krawczyk, M.; Wang, W.; Luo, H.; Flagg, K.; Yi, S.; Shi, W.; Quan, Q.; Li, K.; et al. Circulating tumour DNA methylation markers for diagnosis and prognosis of hepatocellular carcinoma. Nat. Mater. 2017, 16, 1155-1161. [CrossRef] [PubMed]

269. Hu, Z.; Ding, J.; Ma, Z.; Sun, R.; Seoane, J.A.; Scott Shaffer, J.; Suarez, C.J.; Berghoff, A.S.; Cremolini, C.; Falcone, A.; et al. Quantitative evidence for early metastatic seeding in colorectal cancer. Nat. Genet. 2019, 51, 1113-1122. [CrossRef]

270. Li, J.; Sun, Z.; Zhang, J.; Shao, H.; Cona, M.M.; Wang, H.; Marysael, T.; Chen, F.; Prinsen, K.; Zhou, L.; et al. A dual-targeting anticancer approach: Soil and seed principle. Radiology 2011, 260, 799-807. [CrossRef] 
271. Murray, I.; Chittenden, S.J.; Denis-Bacelar, A.M.; Hindorf, C.; Parker, C.C.; Chua, S.; Flux, G.D. The potential of (223)Ra and (18)F-fluoride imaging to predict bone lesion response to treatment with (223)Ra-dichloride in castration-resistant prostate cancer. Eur. J. Nucl. Med. Mol. Imaging 2017, 44, 1832-1844. [CrossRef]

272. Werner, R.A.; Lapa, C.; Ilhan, H.; Higuchi, T.; Buck, A.K.; Lehner, S.; Bartenstein, P.; Bengel, F.; Schatka, I.; Muegge, D.O.; et al. Survival prediction in patients undergoing radionuclide therapy based on intratumoral somatostatin-receptor heterogeneity. Oncotarget 2017, 8, 7039-7049. [CrossRef]

273. Chang, C.H.; Sharkey, R.M.; Rossi, E.A.; Karacay, H.; McBride, W.; Hansen, H.J.; Chatal, J.F.; Barbet, J.; Goldenberg, D.M. Molecular advances in pretargeting radioimunotherapy with bispecific antibodies. Mol. Cancer Ther. 2002, 1, 553-563.

274. Milano, M.T.; Constine, L.S.; Okunieff, P. Normal tissue tolerance dose metrics for radiation therapy of major organs. Semin. Radiat. Oncol. 2007, 17, 131-140. [CrossRef]

275. Michalski, J.M.; Gay, H.; Jackson, A.; Tucker, S.L.; Deasy, J.O. Radiation dose-volume effects in radiation-induced rectal injury. Int. J. Radiat. Oncol. Biol. Phys. 2010, 76, 123-129. [CrossRef]

276. Dawson, L.A.; Kavanagh, B.D.; Paulino, A.C.; Das, S.K.; Miften, M.; Li, X.A.; Pan, C.; Ten Haken, R.K.; Schultheiss, T.E. Radiation-Associated Kidney Injury. Int. J. Radiat. Oncol. Biol. Phys. 2010, 76, 108-115. [CrossRef] [PubMed]

277. Zhang, J.; Wang, H.; Jacobson, O.; Cheng, Y.; Niu, G.; Li, F.; Bai, C.; Zhu, Z.; Chen, X. Safety, Pharmacokinetics, and Dosimetry of a Long-Acting Radiolabeled Somatostatin Analog (177)Lu-DOTA-EB-TATE in Patients with Advanced Metastatic Neuroendocrine Tumors. J. Nucl. Med. 2018, 59, 1699-1705. [CrossRef] [PubMed]

278. Dawson, L.A.; Ten Haken, R.K. Partial volume tolerance of the liver to radiation. Semin. Radiat. Oncol. 2005, 15, 279-283. [CrossRef] [PubMed]

279. Rolleman, E.J.; Kooij, P.P.; de Herder, W.W.; Valkema, R.; Krenning, E.P.; de Jong, M. Somatostatin receptor subtype 2-mediated uptake of radiolabelled somatostatin analogues in the human kidney. Eur. J. Nucl. Med. Mol. Imaging 2007, 34, 1854-1860. [CrossRef] [PubMed]

280. Reubi, J.C.; Horisberger, U.; Studer, U.E.; Waser, B.; Laissue, J.A. Human kidney as target for somatostatin: High affinity receptors in tubules and vasa recta. J. Clin. Endocrinol. Metab. 1993, 77, 1323-1328. [CrossRef] [PubMed]

281. Abma, E. Ugent Is Looking For Dogs With Malignant Tumors. Available online: https://www.dierenartsenwereld. be/nl/nieuws-n2/ugent-zoekt-honden-met-kwaadaardige-tumoren-i171/ (accessed on 7 November 2019).

282. OncoCiDia Phase 0 study (3M150468). Available online: https://www.kuleuven.be/onderzoek/portaal/\#/ projecten/3M150468?hl=en\&lang=en (accessed on 7 November 2019).

283. Petrelli, A.; Giordano, S. From single- to multi-target drugs in cancer therapy: When aspecificity becomes an advantage. Curr. Med. Chem. 2008, 15, 422-432.

284. Bang, Y.-J.; Van Cutsem, E.; Feyereislova, A.; Chung, H.C.; Shen, L.; Sawaki, A.; Lordick, F.; Ohtsu, A.; Omuro, Y.; Satoh, T.; et al. Trastuzumab in combination with chemotherapy versus chemotherapy alone for treatment of HER2-positive advanced gastric or gastro-oesophageal junction cancer (ToGA): A phase 3 , open-label, randomised controlled trial. Lancet 2010, 376, 687-697. [CrossRef]

285. Liu, Y.; Yin, T.; Keyzer, F.D.; Feng, Y.; Chen, F.; Liu, J.; Song, S.; Yu, J.; Vandecaveye, V.; Swinnen, J.; et al. Micro-HCCs in rats with liver cirrhosis: Paradoxical targeting effects with vascular disrupting agent CA4P. Oncotarget 2017, 8, 55204-55215. [CrossRef]

286. Pantel, K.; Alix-Panabieres, C. Liquid biopsy and minimal residual disease-latest advances and implications for cure. Nat. Rev. Clin. Oncol. 2019, 16, 409-424. [CrossRef]

287. Descotes, F.; Kara, N.; Decaussin-Petrucci, M.; Piaton, E.; Geiguer, F.; Rodriguez-Lafrasse, C.; Terrier, J.E.; Lopez, J.; Ruffion, A. Non-invasive prediction of recurrence in bladder cancer by detecting somatic TERT promoter mutations in urine. Br. J. Cancer 2017, 117, 583. [CrossRef]

288. Dudley, J.C.; Schroers-Martin, J.; Lazzareschi, D.V.; Shi, W.Y.; Chen, S.B.; Esfahani, M.S.; Trivedi, D.; Chabon, J.J.; Chaudhuri, A.A.; Stehr, H.; et al. Detection and Surveillance of Bladder Cancer Using Urine Tumor DNA. Cancer Discov. 2019, 9, 500-509. [CrossRef]

289. Pan, H.; Gray, R.; Braybrooke, J.; Davies, C.; Taylor, C.; McGale, P.; Peto, R.; Pritchard, K.I.; Bergh, J.; Dowsett, M.; et al. 20-Year Risks of Breast-Cancer Recurrence after Stopping Endocrine Therapy at 5 Years. N. Engl. J. Med. 2017, 377, 1836-1846. [CrossRef]

290. Liu, C.; Zhao, J.; Tian, F.; Cai, L.; Zhang, W.; Feng, Q.; Chang, J.; Wan, F.; Yang, Y.; Dai, B.; et al. Low-cost thermophoretic profiling of extracellular-vesicle surface proteins for the early detection and classification of cancers. Nat. Biomed. Eng. 2019, 3, 183-193. [CrossRef] [PubMed] 
291. Sanger, N.; Effenberger, K.E.; Riethdorf, S.; Van Haasteren, V.; Gauwerky, J.; Wiegratz, I.; Strebhardt, K.; Kaufmann, M.; Pantel, K. Disseminated tumor cells in the bone marrow of patients with ductal carcinoma in situ. Int. J. Cancer 2011, 129, 2522-2526. [CrossRef] [PubMed]

292. Harper, K.L.; Sosa, M.S.; Entenberg, D.; Hosseini, H.; Cheung, J.F.; Nobre, R.; Avivar-Valderas, A.; Nagi, C.; Girnius, N.; Davis, R.J.; et al. Mechanism of early dissemination and metastasis in Her2(+) mammary cancer. Nature 2016, 540, 588-592. [CrossRef] [PubMed]

293. Hosseini, H.; Obradovic, M.M.S.; Hoffmann, M.; Harper, K.L.; Sosa, M.S.; Werner-Klein, M.; Nanduri, L.K.; Werno, C.; Ehrl, C.; Maneck, M.; et al. Early dissemination seeds metastasis in breast cancer. Nature 2016, 540, 552-558. [CrossRef] [PubMed]

C 2019 by the authors. Licensee MDPI, Basel, Switzerland. This article is an open access article distributed under the terms and conditions of the Creative Commons Attribution (CC BY) license (http://creativecommons.org/licenses/by/4.0/). 